\title{
Religioznost i stavovi prema imigrantima u Hrvatskoj
}

DOI: https://doi.org/10.11567/met.34.3.3

UDK: 2:316.64]:314.151.3-054.56(497.5)

Izvorni znanstveni rad

Primljeno: 29.04.2019.

Prihvaćeno: 18.06.2019.

\section{Josip Kumpes}

Institut za migracije i narodnosti, Zagreb

josip.kumpes@imin.hr

\section{SAŽETAK}

Migracije su postale goruće pitanje suvremenoga svijeta, a imigranti »inkarnacija autsajdera «. Sve učestalije naglašavanje njihove kulturne i pritom dominantno religijske različitosti od većinskoga stanovništva u zemljama primitka poticaj je za istraživanje povezanosti religije i migracija. U radu se na temelju empirijskog istraživanja stavova prema stranim radnicima u Hrvatskoj propituje postoji li povezanost između religioznosti i stavova prema imigrantima te religija kao simbolička granica prema imigrantima. U prvom dijelu rada problematizira se primarno sociološki pristup istraživanju povezanosti religije i imigracije. Potom se iznose i analiziraju rezultati istraživanja provedenoga s pomoću anketnoga upitnika na reprezentativnom uzorku od 1300 punoljetnih hrvatskih građana i građanki. Pritom se dovode u vezu dimenzije religioznosti (religijska samoidentifikacija, konfesionalna samoidentifikacija i religijska praksa), stav prema povezanosti religijskoga i nacionalnog identiteta i izražena društvena distanca prema pripadnicima drugih religija (nekatolicima), kao nezavisne varijable, s izraženim stavovima prema stranim (imigrantskim) radnicima. Pokazalo se da su sve tri istraživane dimenzije religioznosti statistički značajno povezane sa stavovima prema imigrantima, odnosno da su oni religiozniji i koji prakticiraju religiju skloniji izraziti veću društvenu distancu prema imigrantima i imigrante percipirati ponajprije kao kulturnu prijetnju. Također se pokazuje da su društvenu distancu prema imigrantima skloni izraziti oni koji imaju stav da su religijsko i nacionalno usko povezani, a osobito oni koji su skloni izraziti društvenu distancu prema pripadnicima drugih religija (nekatolicima).

KLJUČNE RIJEČI: religija, religioznost, migracije, simboličke granice, društvena distanca, stavovi prema imigrantima 


\section{UVOD}

Vrata mogu biti zaključana, ali problem neće nestati koliko god brava bila čvrsta. Brave ne poduzimaju ništa kako bi ukrotile ili oslabile sile koje uzrokuju raseljavanje i ljude pretvaraju u izbjeglice. Brave mogu pomoći da se problem makne iz vidokruga $i$ smetne s uma, ali ne $i$ da prestane postojati.

Zygmunt Bauman, 2002: 85

Metaforičke ograde građene političkim odlukama i moralnom panikom nakon rujna 2001. o kojima govori Bauman u međuvremenu rastu, a negdje se pretvaraju i u stvarne. Već na samom početku svoje knjige Slika migranta Thomas Nail (2015) kaže da će 21. stoljeće biti stoljećem migranta. Iako ga obilježavaju intenziviranje i omasovljenje migracija, osobito onih prisilnih (v. npr. IOM, 2017; European Parliament, 2017), teško bi se moglo reći da će baš to biti specifičnost, ne previše odmaklog, 21. stoljeća (usp. npr. Bauman, 2016). Ono što ga čini drukčijim u odnosu na prethodna razdoblja, a vezano je uz migracije, možda i više od njihove masovnosti, jest istovremenost mnogobrojnih čimbenika koji ljude potiču i tjeraju na migriranje: razornih ratova, rigidnih političkih režima, osiromašenih gospodarstava, klimatskih promjena i u svakom smislu opustošenih zemalja. Osebujnost 21. stoljeća jest i vidljivost migracija i migranata bez odgode, hic et nunc, jer nove tehnologije više nego ikad prije omogućuju nezaustavljivo kolanje vijesti. Vijesti, kako provjerene tako i one neprovjerene, ${ }^{1}$ poduprte političkom upotrebom migracija i migranata čine migracije vidljivima i bez stvarne prisutnosti imigranata u zemljama primitka, čak i u onima koje bi to tek mogle postati. ${ }^{2}$ Tako stvorene predodžbe o migracijama učinile su od

Za razliku od primjerice Međunarodne organizacije za migracije koja u svojim izvještajima opetovano naglašava nepouzdanost prikupljenih podataka zbog ograničenja u njihovu prikupljanju, društvene mreže, internetski portali i sl. obiluju neprovjerenim i nerijetko netočnim podacima na temelju kojih oni koji ih prate stvaraju svoje predodžbe.

2 Istraživanja pokazuju sklonost da se precjenjuje udio imigranata u ukupnom stanovništvu u zemljama primitka (Citrin i Sides, 2008). Ilustrativan je primjerice Eurobarometrov podatak za zemlje Europske unije, u kojima trećina ispitanika 2017. godine nije mogla procijeniti broj stranaca koji nisu porijeklom iz zemalja Europske unije u svojim zemljama. Oni koji su procijenili uglavnom su precijenili udio imigranata. Izuzetak su Hrvatska, Estonija i Švedska, u kojima su ispitanici, redom, potpuno točno procijenili, blago podcijenili i blago precijenili njihov udio u ukupnom stanovništvu svoje zemlje. U svim ostalim zemljama precijenili su njihov udio, a u devetnaest zemalja čak dvostruko i više. Među njima se posebno ističu Rumunjska, Bugarska i Poljska, gdje je dojam o udjelu imigranata osam puta veći od njihova stvarnog broja, i Slovačka, u kojoj je procjena veća čak četrnaest puta (European Commission, 2018). 
njih problem, dijelom, čini se, i u thomasovskom smislu riječi, tj. budući da ih se percipira kao problem, migracije jesu problem (usp. Nelson, 2009). No ni takva interpretacija ne čini ih manjim ni manje važnim problemom. Iako je tome na svaki način pridonijela stvarna masovnost migracija kao posljedica ukupne društveno-povijesne situacije koja ljude tjera na migriranje, nezanemariv je odgovor zemalja primitka ili potencijalnih zemalja primitka s druge strane.

Širenje moralne panike jedan je od sve učestalijih odgovora na migracijska kretanja unatoč tome što istraživanja pokazuju da većina Europljana podupire otvorenu Europu. Političari i mediji, poglavito oni s desne i krajnje desne strane političkoga spektra, nastoje imigrante predstaviti kao sigurnosni i svaki drugi problem u svima, makar i potencijalnim, zemljama primitka (v. npr. Huddleston i Mikaba, 2017). Stoga, za razliku od prisutne, ali stišane uključivosti prema imigrantima, isključivost glasno odjekuje kroz sve masovnije zahtjeve za zatvaranjem granica te kroz rezultate političkih izbora i referenduma koji daju na znanje kakvo je raspoloženje prema imigrantima diljem sve negostoljubivijeg ekonomski razvijenijeg dijela svijeta, ciljanog ideala migranata iz onog njegova dijela koji je osiromašen, razoren ratom i opustošen (v. npr. Futile debates around the Global Compact for Migration..., 2018).

Ksenofobofilija, tj. političko iskorištavanje ksenofobnih nagnuća u općoj populaciji, na koju se upozorava još od sredine osamdesetih, kad je i skovan taj pojam (Evrigenis, 1985), u porastu je skupa sa ksenofobijom, što tvori svojevrsni društveni perpetuum mobile treće vrste. Imigrante koji dolaze iz dominantno islamskih zemalja, kao da je riječ o islamistima, nerijetko se $\mathrm{u}$ javnosti povezuje $\mathrm{s}$ terorizmom i na taj način manipulira strahom od masovnosti migracija iz islamskoga svijeta i mogućega razornog islamskog utjecaja na kršćanske kulturne temelje suvremenih imigracijskih društava. ${ }^{3}$ Stoga se u suvremenim imigracijskim zemljama ksenofobija sve češće manifestira ponajprije kao islamofobija (v. npr. Pickel, 2018; Brubaker, 2015; Strabac, Aalberg i Valenta, 2014).

Ne ulazeći u daljnje razmatranje ove uvodne skice društveno-povijesnoga konteksta, valja skrenuti pažnju na još jednu njegovu osobitost koja se sve

Gotovo se čini suvišnim podsjećati na sve pokrete, stranke i procese koji se usredotočuju na tu tematiku i potiču stanja kolektivne uzavrelosti ne sagledavajući društvene posljedice izvan svojih kratkoročnih populističkih namjera (v. npr. Understanding Pegida in Context, 2015; Bauman, 2016; Gow i Meyer, 2016). O porastu populizma i njegovim ideološkim pomacima govori Brubaker (2017) uvodeći pojam civilizacionizma, pod kojim podjednako podrazumijeva novu artikulaciju nacionalizma i alternativu nacionalizmu. 
češće nameće kao istraživački problem, a to je povezanost religije i suvremenih migracija te, točnije, naglašeno skretanje pozornosti na religijsku različitost imigranata od domaćega stanovništva.

Unatoč toj tendenciji, treba reći da, kao ni masovna imigracija, ni religijska pluralnost nije novost $\mathrm{u}$ imigracijskim zapadnoeuropskim društvima. Ona se postupno povećavala još od sredine 20. stoljeća s prvim programima privlačenja stranih radnika i useljavanjima iz nekadašnjih kolonija. No, kao što je »većini europskih zemlja još uvijek (...) teško sebe vidjeti kao trajno imigrantska društva, a rođene u inozemstvu ili čak u njima rođenu drugu i treću generaciju kao svoje državljane bez obzira na njihov pravni status«, tako europska sekularna društva, unatoč tendenciji da poštuju i toleriraju individualnu religijsku slobodu, pod pritiskom privatizacije religije na muslimansku religioznost gledaju s nepovjerenjem (Casanova, 2007: 60). Štoviše, Casanova smatra da zbog toga što se $\mathrm{u}$ antimuslimanski diskurs diljem Europe neselektivno uvrštavaju »[a]ntiimigrantski ksenofobični nativizam, sekularističke antireligijske predrasude, liberalno-feministička kritika muslimanskog patrijarhalnog fundamentalizma i strah od islamističkih terorističkih mreža «, ne postoje temeljni preduvjeti za uspješnu inkorporaciju (muslimanskih) imigranata u društva primitka (Casanova, 2007: 65).

Drugim riječima, kako dijagnosticira Hervieu-Léger (2007: 203), problem se nameće kad pridošlice počnu remetiti uspostavljeni način odnosa prema religiji u javnom prostoru. $S$ time u vezi ona se pita jesu li zapadnoeuropske institucije spremne i sposobne suočiti se s izazovima religijske suvremenosti. Isto bi se pitanje moglo postaviti i za donedavno emigracijska društva, kako ona južnoeuropska, poput talijanskoga, s katoličkim monopolom i neočekivanom religijskom pluralnošću (Pace, 2014) tako i ona Srednje i Jugoistočne Europe obilježena inherentnom društveno-povijesno ukorijenjenom međusobnom, a nerijetko i unutarnjom religijskom različitošću, zbog koje ih je i u tom smislu teško svrstati, iako se to često uobičava, u jedinstvenu skupinu postkomunističkih društava (usp. Zrinščak, 2014). Riječju, dinamika odnosa između imigranata i društva primitka i potreba njezina razumijevanja čini, između ostalih čimbenika, onaj religijski koliko složenim toliko i nezaobilaznim $\mathrm{u}$ istraživanjima migracija.

Dakako, nije novost ni da su religija i religioznost dijelom istraživanja migracija, poglavito socioloških. No ta se povezanost uglavnom zahvaćala ili iz perspektive sociologije migracija ili pak sociologije religije, što je određivalo fokus i aspekt povezivanja dvaju fenomena. Zato se u ovome radu najprije nudi kratak uvid u dosadašnja sociološka istraživanja obiju perspektiva, 
a potom se pokušava postaviti problem sociološkog istraživanja odnosa između religije i migracije na primjeru istraživanja provedenoga u $\mathrm{Hr}$ vatskoj na reprezentativnome uzorku punoljetnih građana. Unatoč tome što je Hrvatska tek moguća imigracijska zemlja i dugoj povijesti njezine višeetničnosti i višekonfesionalnosti, pokazalo se da se u velikoj mjeri moguće strane radnike doživljava ponajprije kao kulturnu prijetnju i prema njima izražava visoka društvena distanca (Čačić-Kumpes, Gregurović i Kumpes, 2012; usp. Čačić-Kumpes, Gregurović i Kumpes, 2014). ${ }^{4}$ Poticaj je to da se, imajući u vidu dosadašnja sociološka istraživanja, ispita postoji li povezanost između dimenzija religioznosti i takvih stavova prema (potencijalnim) stranim (imigrantskim) radnicima u Hrvatskoj.

\section{ISTRAŽIVANJA POVEZANOSTI RELIGIJE I MIGRACIJE}

Sociološko bavljenje istraživanjem povezanosti religije i migracija na različite je načine umnogome i višestruko društveno-povijesno određeno. Kivisto (2016) i Foner i Alba (2008) primjerice takvu tvrdnju zasnivaju na razlikama u temama na koje se usredotočuju američki i zapadnoeuropski sociolozi, a koje proizlaze iz društvenoga i povijesnoga konteksta unutar kojega istražuju. Tako Foner i Alba (2008: 361) u svojoj analizi navode da se u Americi malo pažnje pridavalo povezanosti religije i imigracije, što zbog činjenice da su podaci o religijskoj strukturi nedostupni jer se službeno ne popisuju, što zbog dojma da se migrantska religioznost u zemlji s visoko naglašenom religioznošću, ne shvaća kao ograničavajući integracijski čimbenik. Nasuprot tome $\mathrm{u}$ dominantno sekularnoj Zapadnoj Europi religioznost imigranata, osobito onih islamske vjeroispovijesti, dugo je u središtu interesa istraživača. Osim što su Foner i Alba tu razliku, kao i poslije Kivisto (2016), povezali i s kontekstnim razlikama između Zapadne Europe i Sjedinjenih Američkih Država, oni izdvajaju tri čimbenika koja na svojevrstan način ne određuju samo istraživačke interese i usredotočenost nego i ulogu religije $u$ društvenim učincima imigracije. Ta su tri čimbenika: razlike

\footnotetext{
Činjenica da se, nasuprot izraženim ksenofobnim stavovima o kojima govore podaci istraživanja, u trenutku »migracijske krize « 2015., manifestirala solidarnost domaćeg stanovništva s migrantima (v. npr. Capo, 2015), mogla bi navesti na pomisao da je stvarnost barem donekle demantirala nalaze istraživanja. Riječ je, međutim, o odnosima koji nisu usporedivi. Ipak, njihovo razmatranje može biti važno za razumijevanje problema solidarnosti koji se pojavljuje kao sastavni dio migracijskih procesa. Ovdje treba dodati da problem solidarnosti jest problem suvremenog svijeta i nužno dijelom sociološkog razmatranja migracija (v. npr. Bauman, 2004, 2016).
} 
$\mathrm{u}$ religijskom porijeklu imigranata između ta dva dijela svijeta, religioznost domaćega stanovništva i institucionalni okvir, tj. povijesno ukorijenjeni odnosi i uređenje odnosa između države i religijskih skupina (Foner i Alba, 2008).

Poput Foner i Albe, i Kivisto (2016) skreće pažnju na to da krajem 20. i u 21. stoljeću zbog masovnosti migracija jača interes istraživača za povezivanje religije i migracija. Iako Kivistova analiza pokazuje različitost tema na koje se usredotočuju sociolozi religije i sociolozi migracija, ona ponajprije govori o sjecištu njihovih interesa - sociolozi religije sve se više usredotočuju na migracije, a sociolozi migracija na religiju. To sjecište proizlazi iz naravi suvremenih migracija, koje pak nije moguće uistinu razumjeti ako se na njih ne gleda integralno, tj. imajući u vidu i zemlje porijekla i zemlje primitka, i imigrante i domaće stanovništvo.

Takvu tvrdnju potkrepljuje, između ostaloga, i izvještaj Istraživačkog centra Pew čiji podaci govore da mnogi Europljani doživljavaju izbjeglice kao prijetnju od porasta terorizma, gubitka posla i socijalnih povlastica, pa i odgovornima za kriminal. ${ }^{5}$ Autori tog izvještaja, Wike, Stokes i Simmons (2016), napominju da većina recentnih izbjeglica dolazi iz zemalja u kojima je islam dominantna religija, ali i procjenjuju da su opisani stavovi domaćega stanovništva prema izbjeglicama dijelom pod utjecajem negativnih stavova prema muslimanima koji već žive u njihovim zemljama te raširene predodžbe da muslimani, zadržavajući svoju kulturno-religijsku posebnost, ne žele prihvatiti stil života i običaje u zemlji primitka. ${ }^{6}$ Pokazalo se da oni ispitanici koji izražavaju negativne stavove prema muslimanima percipiraju izbjeglice iz Sirije i Iraka kao glavnu prijetnju (Wike, Stokes i Simmons, 2016: 29). Osim toga utvrdili su da su negativni stavovi prema imigrantima u pozitivnoj korelaciji s desnom i ekstremno desnom političkom orijentacijom, a takvi su i nalazi mnogobrojnih drugih istraživanja stavova o imigran-

\footnotetext{
Istraživanje je provedeno u proljeće 2016. u Grčkoj, Francuskoj, Italiji, Mađarskoj, Nizozemskoj, Njemačkoj, Poljskoj, Španjolskoj, Švedskoj i Velikoj Britaniji. U osam od deset tih država polovina ili više ispitanika vjeruje da se dolaskom izbjeglica povećava mogućnost za terorizam u njihovim zemljama. U to vjeruje najmanje ispitanika u Španjolskoj i Francuskoj, ali i tamo njih $40 \%$ odnosno $46 \%$. Strah da će ostati bez posla i socijalnih prava najveći je problem koji se u Mađarskoj, Poljskoj, Grčkoj, Italiji i Francuskoj veže uz izbjeglice. Povezivanje izbjeglica s mogućim porastom kriminala manje je izraženo od povezivanja sa strahom od terorizma i gubitka posla, ali iako u manjoj mjeri, ipak od 13\% (u Španjolskoj) do $47 \%$ ispitanika (u Italiji) smatra izbjeglice više nego druge skupine odgovornima za kriminal (Wike, Stokes i Simmons, 2016: 3-5).

6 Kad je riječ o spomenutim predodžbama lokalnoga stanovništva o muslimanima, sociolozima migracija ne može promaknuti zdravorazumsko i nestručno tumačenje kulturnih politika koje izjednačuje ideje (i politike) asimilacije i integracije, kao ni tendencija da $u$ javnim politikama (pa i u znanstvenome diskursu) integracija potiskuje multikulturalizam i interkulturalizam.
} 
tima (v. npr. Rydgren, 2018; Huddleston i Mikaba, 2017; Minkenberg, 2017; Schain, 2017; Perrineau, 2016; Vučković Juroš, Dobrotić i Zrinščak, 2014; Karyotis i Patrikios, 2010; Semyonov, Raijman i Gorodzeisky, 2006). ${ }^{7}$

Autori izvještaja međutim ne spominju da su istraživali povezanost između religioznosti ispitanika i njihovih stavova prema imigrantima. Možda razloge treba tražiti u tome što rezultati nekih istraživanja pokazuju da nema konzistentne povezanosti između dimenzija religioznosti i stavova prema imigrantima. Na poteškoće u utvrđivanju povezanosti religijskih varijabli i stavova prema imigraciji i imigrantima opominju primjerice Ceobanu i Escandell (2010), koji kažu da je to djelomično moguće objasniti oklijevanjem istraživača da poduzmu dodatna istraživanja toga odnosa, a što, s obzirom na raširenost toga problema, smatraju nezadovoljavajućim. ${ }^{8}$

Scheepers, Gijsberts i Hello također opominju na ograničenja istraživanja o povezanosti religioznosti i predrasuda prema etničkim manjinama (kako u svome istraživanju nazivaju imigrante). Stoga su istraživali različite dimenzije religioznosti u jedanaest europskih zemalja. Zaključili su da nakon pet desetljeća istraživanja mogu tvrditi, barem za europske zemlje, uz koje se dimenzije religioznosti vežu etničke predrasude (pripadnost kršćanskim denominacijama, pohađanje crkve i osobito religijski partikularizam), a koje ih dimenzije smanjuju (doktrinarna uvjerenja, važnost religije i individualna duhovnost). Pokazali su prediktivnu sposobnost religioznosti i utvrdili da ona nije prividna, a da to osobito nije kad se uključe kontekstna obilježja (Scheepers, Gijsberts i Hello, 2002: 259; v. i Scheepers i Eisinga, 2015). ${ }^{9}$ Poznavanje i analiza kontekstnih razlika važni su za svaki pokušaj razumijevanja razlika dobivenih $\mathrm{u}$ analizama stavova vezanih uz religiju i imigraciju (v. npr. Mathieu, 2010; Knoll, 2009; Gołębiowska, 2009; Joppke, 2004).

Treba napomenuti da neka usporedna istraživanja ne pokazuju konzistentnost između stavova prema imigrantima i identifikacije na konvencionalnoj skali političke orijentacije lijevo - desno. Tako se primjerice političko opredjeljenje u istraživanju Citrina i Sidesa u Poljskoj, Češkoj i Mađarskoj nije pokazalo prediktorom stavova prema imigrantima (v. Citrin i Sides, 2008: 47-48), a što $\mathrm{u}$ istraživanjima u zapadnoeuropskim zemljama i SAD-u uglavnom nije slučaj.

8 Instruktivan je nalaz Johnson Shen i njezinih suradnika (2013) u istraživanju povezanosti dviju komponenti religioznosti, vjerovanja u Boga i rigidnosti, odnosno fleksibilnosti religijskih vjerovanja i stavova prema »rasno« i vrijednosno drukčijima. Pokazalo se da se istraživane komponente religioznosti ne pokazuju kao prediktori predrasuda, nego da to koja će se komponenta religioznosti pokazati prediktorom ovisi o vrsti predrasude koja se istražuje.

9 Vučković Juroš, Dobrotić i Zrinščak (2014: 248) utvrdili su, na temelju istraživanja povezanosti religijske (konfesionalne) identifikacije i društvene distance prema imigrantima u "postkomunističkim i južnoeuropskim zemljama«, da se religijski/konfesionalni identitet za razliku od drugih dimenzija religioznosti pokazao značajnom varijablom. 
$\mathrm{Na}$ važnost društveno-povijesnoga konteksta izričito upozoravaju autori koji su pokušali usporedno analizirati stavove prema imigrantima i imigraciji bez obzira na to povezuju li ih s religijom i religioznošću ili ne (v. npr. Davidov i Semyonov, 2017; Fullin, 2016; Nagayoshi i Hjerm, 2015; Ceobanu i Escandell, 2010; Hello, Scheepers i Gijsberts, 2002). Ceobanu i Escandell upozoravaju da kontekstne razlike u višenacionalnim istraživanjima predstavljaju istraživačima problem i suočavaju ih s teorijskim ograničenjima i metodološkim izazovima.

Izdvajaju se pritom problemi terminološke nejednoznačnosti, koja otežava komparativna istraživanja, i suženost teorijske i analitičke usredotočenosti na teorije kompeticijske prijetnje i na individualnoj i na makrorazini. Prediktori stavova prema imigrantima i imigraciji uglavnom su strukturne i individualne naravi, a pokazuje se da su negativni stavovi prema imigraciji i imigrantima međusobno slični bez obzira na razlike među pojedinim zemljama i njihovim imigracijskim politikama i povijestima, kažu Ceobanu i Escandell (2010:311). Potporu nalaze između ostaloga u istraživanjima Citrina i Sidesa, koji su uspoređujući rezultate istraživanja s obje strane Atlantika ustanovili sindrom stavovskog prožimanja, univerzalnu sklonost domaćeg stanovništva da precjenjuje broj imigranata u svojim zemljama i izražava želju da se smanji broj imigranata u njihovoj zemlji (Citrin i Sides, 2008; v. i European Commission, 2018). Osim toga u svim se zemljama pokazalo da osobni stavovi ispitanika i njihove političke vrijednosti imaju snažan učinak na stavove prema imigraciji i imigrantima, a osobito društveno povjerenje i stavovi prema kulturnoj i vjerskoj homogenosti. Kad je o razlikama u stavovima riječ, zaključili su da su one sukladne različitim nacionalnim mitovima i iskustvu sa stranom populacijom te da ispitanike najviše zabrinjava mogućnost integracije imigranata (Citrin i Sides, 2008: 51) pa bi se razloge njihova pojavljivanja stoga trebalo tražiti u kontekstnim razlikama.

Kontekstne razlike na svojevrstan način određuju i istraživačke teme, fokus i metodologiju socioloških istraživanja povezanosti migracija i religije. ${ }^{10}$ Dakako, moglo bi se reći da je taj nalaz podjednako plauzibilan i samorazumljiv jer sociološku imaginaciju nije ni moguće odvojiti od društveno-

10 Čini se da je, primjerice, istraživanjem o dinamici antiimigrantskih stavova vezanoj uz dinamiku sigurnosnih diskursa provedenim u Grčkoj moguće dodatno argumentirati važnost specifičnoga društvenoga konteksta $u$ istraživanju povezanosti religije i migracija. Ono, osim toga što je temeljno motivirano da raspravi metodološke probleme empirijskih istraživanja na sigurnosnom području, pokazuje smjenu pojedinih društvenih aktera (političara i Pravoslavne crkve) u uporabi sigurnosnog diskursa povezanoga s migrantima, argumentira razloge njihova posezanja za njim društvenim kontekstom i njihovim interesima te tako objašnjava postojanost antiimigrantskih stavova u Grčkoj (Karyotis i Patrikios, 2010). 
povijesnoga konteksta koji je poticaj za istraživanje i interpretacijski okvir njegovih rezultata. To ne znači priklanjanje metodološkom nacionalizmu, nego nastojanje za složenijim i rafiniranijim istraživačkim postupcima.

Važnost takva pristupa pokazuje i istraživanje Christophera A. Baila (2008) o simboličkim granicama prema imigrantima u Europi. Ono se bavi mikrorazinom uspostavljanja tih granica $u$ pojedinim europskim regijama $\mathrm{i}$ njihovim prerastanjem $u$ društvene granice. Baila zanimaju koncepcijske razlike ili simboličke granice s pomoću kojih društveni akteri (pojedinci i skupine) tvore i obnavljaju svoje relacijske identitete, tumače stvarnost, što i jest funkcija granica na individualnoj razini (Lamont, 1992), koje, kao i njihova važnost, variraju od društva do društva. Na makrorazini definiranje simboličkih granica u službi je očuvanja poretka i uspostavljanja reda među zajednicama s pomoću jačanja kolektivnih normi (Lamont, 1992). Simboličke granice tako nisu samo koncepcijsko sredstvo za definiranje razlika kao osnove društvenoga kategoriziranja, nego i oružje u borbi za privilegije, pa i moguće društveno isključivanje (Lamont i Molnár, 2002: 168-169). Simboličke granice ${ }^{11} \mathrm{u}$ tome su smislu, slaže se i Bail (2008), neophodan, ali nedostatan uvjet za uspostavljanje društvenih granica. ${ }^{12}$ Društvene su granice opredmećene i institucionalizirane simboličke granice koje se manifestiraju primjerice u postojanju geta, ekskluzivnih klubova, »rasne« i rodne segregacije (v. Lamont, 1992: 9). Da bi se moglo objasniti složeni odnos između simboličkih i društvenih granica, naglasak treba biti, smatra Bail, na višedimenzionalnosti i promjenjivosti simboličkih granica. Pritom bi pažnja trebala biti usmjerena na konfiguraciju većeg broja simboličkih granica. Religija se u tim konfiguracijama u nekim društvima ističe više, a u nekima manje.

Kad se o odnosu između simboličkih i društvenih granica misli u vezi s masovnim suvremenim migracijskim kretanjima, onda se simboličke granice pokazuju $\mathrm{u}$ individualnim stavovima prema imigrantima, a društvene se mogu prepoznati u posljedicama tih stavova: opredmećene u neurednim i nedostojnim uvjetima života u izbjegličkim naseljima na granicama, ograđivanju državnih granica zidovima i žilet-žicom, oblikovane u imigraci-

11 Lamont (1992) u svome je usporednom istraživanju francuske i američke više srednje klase namjeravala utvrditi razlike među pripadnicima te klase u Francuskoj i SAD-u u povlačenju kulturnih granica. Već je na početku istraživanja utvrdila da je potrebno razlikovati tri vrste simboličkih granica: moralne, socioekonomske i kulturne. Nadalje, prema Lamont, simboličke i društvene granice jednako su stvarne, samo što se simboličke manifestiraju u odnosu između pojedinaca, a društvene između pripadnika različitih skupina.

12 U ovome će se radu zadržati distinkcija između simboličke i društvene granice kako ih definira Lamont (1992) iako bi se ona mogla problematizirati (v. npr. Jenkins, 2015). Ona ima opravdanja u kontekstu u kojem su imigranti više zamišljeni nego stvarni »drugi«. 
jskim politikama, izražene $\mathrm{u}$ aktivnom otporu prema izgradnji prihvatnih centara za azilante u lokalnim zajednicama i sl. ${ }^{13} \mathrm{U}$ tome kontekstu u kojem većina imigranata dolazi iz dominantno muslimanskih zemlja u dominantno kršćansku Europu religija se tim više čini simboličkom granicom na koju se valja usredotočiti u istraživanjima. Polazeći s toga stajališta i od činjenice, na koju podsjeća i Bail (2008), da važnost religije kao simboličke granice, kao, uostalom, i drugih etničkih označitelja i kulturnih obilježja, varira od društva do društva, hrvatsko se društvo čini dobrim primjerom iz više razloga.

\section{DRUŠTVENA KONTEKSTUALIZACIJA RELIGIJSKOGA ČIMBENIKA U ISTRAŽIVANJU STAVOVA PREMA IMIGRANTIMA U HRVATSKOJ}

Kad se usredotočuje na povezanost religije i imigracije, a polazi se od nalaza usporednih istraživanja stavova prema imigrantima koji govori o važnosti uvažavanja specifičnosti pojedinih zemlja iz metodoloških razloga (v. npr. Ceobanu i Escandell, 2010; Citrin i Sides, 2008; Sides i Citrin, 2007), onda valja imati na umu nekoliko obilježja hrvatskoga društva.

Ponajprije, riječ je o društvu koje ima dugu povijest višeetničnosti i višekonfesionalnosti u okviru višeetničkih i višekonfesionalnih država. Nadalje, četverostruku tranziciju (Kuzio, 2001) kroz koju je ono prošlo snažno su obilježili nacionalna homogenizacija i rat. ${ }^{14}$ Naposljetku, ulaskom u Europsku uniju stanovništvu tradicionalno emigracijskoga društva otvorila se

13 Slikovitim prikazom transformiranja simboličke u društvenu granicu mogao bi se smatrati Agierov opis scene iz 2009. u Patrasu, lučkome grčkom gradu preko kojega se imigranti nastoje domoći Zapadne Europe. Prema tome opisu, vježbači kroz prozor svoga fitness-kluba, ne prekidajući svoje vježbanje, nijemo promatraju mlade afganistanske imigrante kako bježe pred policajcima i izbjegavaju njihove ponižavajuće stupice. Za njih taj prizor, čini se prema opisu, nije stvarniji od gledanja slične scene na filmskome platnu. »(Ne)odnos« triju aktera koji međusobno ne komuniciraju, lovaca, lovine i promatrača, Agier je definirao kao »neku vrstu srži stanja svijeta « (Agier, 2013: 9-10). Prisutna je indiferentnost promatrača pred prizorom u kojem odnos predatora i lovine nije posljedica biološki zadane puke borbe za opstanak, nego institucionaliziranog nasilja nad slabijim i nepoželjnim drugim, onim koji nije »naš«, pa mu je moguće čak oduzeti i ljudskost i društveno legitimirati odsutnost solidarnosti.

14 Uz uobičajeni pojam dvostruke tranzicije (demokracija/tržište) i njegovo proširenje na trostruku tranziciju (demokracija/tržište/državotvorstvo), o kakvoj primjerice govori Offe (2004), za potrebe analize postkomunističkih zemalja nastalih nakon raspada višenacionalnih država uvodi se pojam četverostruke tranzicije zbog analitičke važnosti etničkoga (nacionalnoga) u njihovoj tranziciji. K tome, Kuzio smatra da »[n]egirati centralnost nacionalnog pitanja za postkomunističke tranzicije znači negirati usku međusobnu povezanost između civilnog društva i etnokulturnih čimbenika u svim građanskim državama« (Kuzio, 2001: 173). Koliko god se pod krovnim pojmom postkomunističkih zemalja nerijetko pojednostavljeno generalizira (v. Zrinščak, 2014), Kuzijev se argument, kad je riječ o hrvatskome kontekstu, čini u punom smislu riječi opravdanim. 
mogućnost još lakšeg iseljavanja, ali i povećali izgledi za priljevom imigranata (Čačić-Kumpes, Gregurović i Kumpes, 2012).

Specifičnije, valja napomenuti da višeetničku strukturu hrvatskoga društva čine autohtone manjine, a da se u Hrvatsku uglavnom doseljavalo iz drugih dijelova višeetničkih država kojih je Hrvatska bila sastavnim dijelom. U najvećem dijelu dvadesetoga stoljeća to je značilo da su doseljenici bili govornici uglavnom istoga ili srodnih jezika i da su dijelili mnoga zajednička kulturna obilježja s većinskim, hrvatskim, stanovništvom. Etnička diferencijacija u povijesti je ponajprije počivala na religiji kao kulturnoj simboličkoj granici. I u tom je smislu Hrvatska, unatoč dominantno kršćanskoj religijskoj strukturi u kojoj prevladavaju katolici, specifična u odnosu na većinu zemalja Europske unije. Naime muslimani su treća najbrojnija religijska skupina, ali, za razliku od ostalih europskih zemalja, u kojima je njihov udio u ukupnome stanovništvu posljedica suvremenih migracija iz bivših kolonija i, najčešće, drugih kontinenata, u Hrvatskoj su oni autohtono manjinsko stanovništvo. ${ }^{15}$ Drugim riječima višeetničnost, višekulturnost i višekonfesionalnost hrvatskoga društva prožete su kulturnom i jezičnom sličnošću etničke većine i mnogobrojnih etničkih i religijskih manjina te obilježene dugom poviješću njihova zajedničkoga života.

U ovome kontekstu treba imati na umu da je Hrvatska visokoreligiozna zemlja koju je, kao i većinu »postkomunističkih « zemalja, obilježila revitalizacija religije (v. npr. Vrcan, 2001; Črpić i Zrinščak, 2005, 2010; Borowik, 2007; Nikodem, 2011; Ančić i Zrinščak, 2012). Istražujući taj fenomen u srednjoeuropskim društvima, Ančić i Zrinščak (2012) uspoređivali su percepcije društvene uloge religije i očekivanja koja građani u tom smislu imaju. Osim što se pokazalo da Hrvatska pripada među najreligioznije zemlje u uzorku, heterogenost percepcije i očekivane uloge religije navodi na to da bi, napominju i sami autori, trebalo dublje zaroniti u društveni i povijesni kontekst da bi se razumjela obilježja religioznosti u Hrvatskoj. S obzirom na obilježja tranzicije u Hrvatskoj, čini se vrijednim propitati povezanost

15 O položaju islamske zajednice u Hrvatskoj i uključenosti muslimanskih vjernika u hrvatsko društvo često se govori kao o primjeru dobre prakse kad se problematiziraju otpor europskog stanovništva prema imigrantima muslimanske vjeroispovijesti i strah od terorizma vezan uz islamski fundamentalizam (v. npr. medijske istupe Aziza ef. Hasanovića, muftije zagrebačkoga, na https://www.islamska-zajednica.hr/interview/intervju-muftije-povodom-konferencijemuslimani-u-europi-prava-i-obaveze i u povezanim tekstovima). Dakako, položaj islamskih vjernika daleko je složeniji, na što na svojevrstan način upućuju rezultati nekih istraživanja (v. npr. Walton, 2015; Mujadžević, 2014). On počiva na dugoj zajedničkoj povijesti s većinskim narodom u nerijetko turbulentnim vremenima, a u kontekstu ovoga rada važno je napomenuti i osjetljivo prožimanje nacionalnoga i religijskog identiteta (v. Hodžić, 2011). 
religijske revitalizacije i nacionalne homogenizacije. $\mathrm{U}$ tome smislu nalazi istraživanja, primjerice Sekulića i Šporer (2006) i Sekulića (2012), mogu biti indikativni.

Propitujući posljedice porasta religioznosti u Hrvatskoj na longitudinalnoj analizi rezultata istraživanja vrijednosnih orijentacija, Sekulić i Šporer (2006) potvrdili su prediktivnu sposobnost religioznosti, ali i da slabije predviđa nacionalizam. To su povezali s činjenicom da su i religioznost $i$ nacionalizam u promatranom razdoblju, između 1985. i 2004., kontinuirano u porastu. Zaključuju da je religioznost povezana s nacionalizmom i da se može pretpostaviti da "religioznost uvjetuje nacionalizam « (Sekulić i Šporer, 2006: 15). Tu povezanost Sekulić poslije potvrđuje i konstatira da se »nacionalizam i religioznost $u$ empirijskoj (...) analizi nalaze zajedno i ne predstavljaju odvojene komponente vrijednosnog sustava « (Sekulić, 2012: 264). ${ }^{16}$ Taj se nalaz čini važnim za analizu uspostavljanja simboličkih, pa i (mogućih) društvenih granica prema imigrantima. S time je u vezi potrebno znati i smatraju li građani religijski/konfesionalni identitet važnom komponentom nacionalnog identiteta. Trittler, Mandes i Koenig (2015: 137-138) utvrdili su da je ta važnost povezana s religijskim nasljeđem u pojedinim zemljama. ${ }^{17}$ Ono je u hrvatskome društvu bogato, ${ }^{18}$ a složeni odnosi države, nacije i religije kroz povijest odrazili su se na dinamiku simboličkih granica jer, kako konstatira Borowik (2007: 656), između ostalih i na hrvatskom primjeru, »religija je povijesno služila - i još uvijek služi - kao oruđe izgradnje i održavanja identiteta, a igrajući skupa s politikom ključnu ulogu«.

$S$ obzirom na to da je religija bila simboličkom granicom $u$ višenacionalnim i višereligijskim državama kojih je Hrvatska bila dijelom, kao i u vrijeme uspostavljanja državne samostalnosti (v. npr. Vrcan, 2006), mogla bi to biti, u osjetljivoj i složenoj igri između religijskoga i nacionalnoga, i u odnosu

16 Taj je zaključak moguće je povezati s pretpostavkom Vučković Juroš, Dobrotić i Zrinščaka (2014: 248-249) kojom pokušavaju objasniti zašto $u$ istraživanju društvene distance prema različitim društvenim skupinama (Romima, muslimanima, homoseksualcima i imigrantima), na uzorku stanovnika 22 postkomunističke i južnoeuropske zemlje, nije bilo moguće utvrditi obrazac povezanosti religijskoga/konfesionalnoga identiteta i istražene društvene distance. Pretpostavljaju da je mogući razlog to što je religijska/konfesionalna identifikacija često izraz kulturne i etničke identifikacije, a ne osobne religioznosti.

17 Pokazalo se da je kršćanski identitet važnija komponenta nacionalnog identiteta za ispitanike iz zemalja s dominantnom pravoslavnom vjerom, odmah zatim katoličkom, a znatno manje u onima s dominantnom protestantskom vjerom. Unatoč sekularnoj predodžbi Europe kršćanski identitet pokazuje se u nekim zemljama, ponajprije onima »nove Europe«, izuzetno važnim (za oko 70\% Poljaka i Bugara, preko 50\% Austrijanaca, Iraca, Talijana i Portugalaca te između 30 i 50\% Mađara, Rusa, Slovaka i Slovenaca) (Trittler, Mandes i Koenig, 2015: 137-138).

18 O povijesnom nasljeđu i ulozi religije u hrvatskome društvu v. više u: Črpić i Zrinščak, 2005: 49-55. 
prema (potencijalnim) imigrantima. U tom smislu važno je posvetiti pažnju kako dimenzijama religioznosti tako i isprepletanju kulturnoga, političkog, nacionalnog i religijskog čimbenika na individualnoj i na društvenoj razini. Naime, i u zemljama poput Hrvatske, u kojima je visok udio onih koji se izjašnjavaju najreligioznijima, kao »uvjereni vjernici«, izraženi stavovi prema imigrantima ne moraju biti u skladu s učenjima njihove religije (v. npr. Župarić-Iljić i Gregurović, 2013), kao što u visokosekulariziranim zemljama poput Francuske nevidljiva kulturno utvrđena religijska granica može imati učinak na odnos političkih vlasti i javnoga mnijenja prema religijskim manjinama (v. Hervieu-Léger, 2001).

Naposljetku, ulaskom u Europsku uniju hrvatske su državne granice postale otvorenije nego ikad za dvosmjerno kretanje stanovništva, pa se nameće pitanje je li tako kad je riječ o simboličkim i društvenim granicama. Na to se pitanje pokušalo odgovoriti istraživanjem stavova prema stranim radnicima, koji se u ovome radu povezuju s nekoliko ispitanih dimenzija religioznosti. Opravdanost toga pristupa pokazuju prethodno opisana komparativna istraživanja stavova prema imigrantima, a nameće ga i njegova relativna zapostavljenost $\mathrm{u}$ hrvatskome kontekstu, $\mathrm{u}$ kojem se imigracijska problematika tek počinje nametati. Rezultati dosadašnjih istraživanja vrijednosti, etničnosti i religije u Hrvatskoj upućuju na njihovo međusobno prožimanje te na potrebu njihova povezivanja radi razumijevanja mnogobrojnih procesa u hrvatskome društvu, pa tako i onoga koji je postao goruće svjetsko pitanje, imigracijskoga procesa.

Ako se uzme $u$ obzir da većina istraživanja u većini imigracijskih zemalja pokazuje da se imigrante doživljava kao prijetnju i to ponajprije kao kulturnu prijetnju (McLaren, 2003; Sides i Citrin, 2007; Citrin i Sides, 2008) te da je slično i u Hrvatskoj (Čačić-Kumpes, Gregurović i Kumpes, 2012), onda je to važno polazište za postavljanje ciljeva istraživanja i istraživačkih pitanja.

\section{CILJEVI ISTRAŽIVANJA}

S obzirom na društveni kontekst u kojem je visoko izražena religioznost, a dolazak imigranata više mogućnost nego stvarnost (ne samo 2009., kad je provedeno empirijsko istraživanje, nego i nakon »migracijske krize« iz 2015.), glavni je cilj istraživanja pokušati utvrditi može li se pojedine ispitane dimenzije religioznosti (religijsku samoidentifikaciju, konfesionalnu samoidentifikaciju i religijsku praksu) smatrati prediktorima stavova hrvatskih građana prema imigrantima i koje su to dimenzije. 
Drugi je cilj istraživanja problematizirati religiju kao simboličku granicu prema imigrantima.

Da bi se to postiglo, postavljaju se sljedeća pitanja:

1. Postoji li povezanost između ispitanih dimenzija religioznosti (religijske samoidentifikacije, konfesionalne samoidentifikacije i religijske prakse) kao nezavisnih varijabli i izražene društvene distance prema stranim radnicima kao zavisne varijable?

2. Postoji li povezanost između ispitanih dimenzija religioznosti (religijske samoidentifikacije, konfesionalne samoidentifikacije i religijske prakse) kao nezavisnih varijabli i percepcije stranih (imigrantskih) radnika kao sociokulturne i socioekonomske prijetnje kao zavisnih varijabli?

3. Postoji li povezanost između stava da su religijsko i nacionalno usko povezani i izražene društvene distance prema stranim radnicima?

4. Postoji li povezanost između izražene društvene distance prema pripadnicima drugih religija (nekatolicima) i izražene društvene distance prema stranim radnicima?

\section{UZORAK I PROVEDBA ISTRAŽIVANJA}

Empirijsko istraživanje provedeno je anketnim ispitivanjem od lipnja do rujna 2009. na reprezentativnom stratificiranom uzorku od 1300 punoljetnih građana i građanki Hrvatske. ${ }^{19}$ Uzorak je stratificiran prema glavnim sociodemografskim obilježjima populacije, s obzirom na spol, dob, stupanj obrazovanja i etničku pripadnost, a kao opća obilježja populacije uzeta su ona dobivena popisom stanovništva u Hrvatskoj 2001.

U tablici 1 navedena je struktura uzorka po spolu, dobnim skupinama, stupnju obrazovanja, samoprocijenjenome socioekonomskom statusu i etničkoj pripadnosti izraženoj samoidentifikacijom.

19 Anketno ispitivanje provedeno je u okviru znanstvenog projekta »Interkulturni pristup etničkoj različitosti i identitet: Hrvatska - Europa«(076-0762385-1516), koji se provodio uz financijsku potporu Ministarstva znanosti, obrazovanja i sporta Republike Hrvatske. 


\section{Tablica 1. Struktura uzorka}

Table 1. Sample characteristics

\begin{tabular}{|c|c|c|c|}
\hline Varijable & Kategorije & $\mathbf{N}$ & $\%$ \\
\hline \multirow{2}{*}{ Spol } & Muški & 624 & 48,0 \\
\hline & Ženski & 676 & 52,0 \\
\hline \multirow{4}{*}{ Dobne skupine } & $18-29$ godina & 273 & 21,0 \\
\hline & $30-49$ godina & 481 & 37,0 \\
\hline & $50-69$ godina & 322 & 24,8 \\
\hline & 70 godina i više & 224 & 17,2 \\
\hline \multirow{3}{*}{ Stupanj obrazovanja } & Osnovna škola ili niže & 533 & 41,9 \\
\hline & Srednja škola & 581 & 45,8 \\
\hline & Viša škola ili više & 156 & 12,3 \\
\hline \multirow{5}{*}{$\begin{array}{l}\text { Samoprocijenjeni } \\
\text { socioekonomski status }\end{array}$} & Puno lošije od većine drugih & 94 & 7,4 \\
\hline & Nešto lošije od većine drugih & 131 & 10,3 \\
\hline & Ni bolje ni lošije od većine drugih & 812 & 63,7 \\
\hline & Nešto bolje od većine drugih & 212 & 16,6 \\
\hline & Puno bolje od većine drugih & 26 & 2,1 \\
\hline \multirow{4}{*}{$\begin{array}{l}\text { Etnička } \\
\text { samoidentifikacija }\end{array}$} & Hrvati & 1157 & 91,8 \\
\hline & Srbi & 65 & 5,2 \\
\hline & Bošnjaci & 12 & 1,0 \\
\hline & Ostali & 27 & 2,1 \\
\hline
\end{tabular}

\section{MJERNI INSTRUMENTI}

Osim sociodemografskih obilježja ispitanika i samoprocijenjenoga socioekonomskog statusa, kao nezavisnih kontrolnih varijabli, te izražene političke orijentacije ispitanika kao dodatne kontrolne varijable u okviru regresijske analize, u okviru rada iz širega anketnog upitnika u analizi se upotrebljavaju mjerni instrumenti koji se odnose na glavne nezavisne mjere, na dimenzije religioznosti, mjerni instrumenti koji se odnose na nezavisne konstrukte, mjeru koja opisuje stav o povezanosti religijskoga i nacionalnog identiteta i mjeru koja opisuje društvenu distancu prema religijskim skupinama, te mjerni instrumenti koji se odnose na zavisne konstrukte koji opisuju stavove prema stranim (imigrantskim) radnicima.

Politička orijentacija ispitana je s pomoću sedmerostupanjske skale (od 1»lijevo« do 7 - »desno«). Rezultati su pokazali da se većina ispitanika pozicionira $u$ »centru « $(48,7 \%)$, dok ih se nešto manje pozicionira lijevo od »centra « $(24,3 \%)$ nego desno od »centra $"(26,8 \%)(\mathrm{M}=4,06 ; \mathrm{SD}=1,41)$. 
Radi utvrđivanja osnovnih indikatora religioznosti ispitane su konfesionalna identifikacija (konfesionalna/religijska pripadnost izražena samoidentifikacijom), religijska samoidentifikacija (odnos prema religiji mjeren kao stupanj religioznosti) te religijska praksa u obliku pohađanja crkve (bogomolje).

Podaci o konfesionalnoj samoidentifikaciji (katoličkoj, pravoslavnoj, muslimanskoj, nekoj drugoj, nijednoj) navedeni su u tablici 2. Rezultati pokazuju visok udio od 94,7\% onih koji su izrazili konfesionalnu/religijsku pripadnost, tj. onih koji se smatraju pripadnicima neke religijske zajednice, dok je samo 5,3\% onih koji ne pripadaju nijednoj konfesiji/religiji. Ispitanici su se većinom identificirali kao katolici, njih čak $86,1 \%$, a to odgovara sličnom udjelu onih koji su u popisu stanovništva 2001. izrazili katoličku konfesionalnu pripadnost $(87,8 \%) .{ }^{20}$ Valja spomenuti da je i u nekim drugim novijim istraživanja u Hrvatskoj utvrđen sličan udio ukupno konfesionalno identificiranih i da se on kreće oko $90 \%( \pm 6 \%)$, a udio katoličke identifikacije iznosi oko 85\% ( $\pm 5 \%$ ) (v. Črpić i Zrinščak, 2010; usp. Nikodem, 2011).

U daljnjim analizama, pri povezivanju te varijable s drugim varijablama, s obzirom na mali broj odgovora u kategorijama »pravoslavni« $\mathrm{i} »$ muslimani« one su pridružene kategoriji »ostali«.

Tablica 2. Konfesionalna samoidentifikacija

Table 2. Confessional self-identification

\begin{tabular}{|l|c|c|}
\hline Konfesionalna samoidentifikacija & $\mathbf{N}$ & $\mathbf{\%}$ \\
\hline Katolici & 1095 & 86,1 \\
\hline Pravoslavni & 56 & 4,4 \\
\hline Muslimani & 34 & 2,7 \\
\hline Ostali & 18 & 1,5 \\
\hline Bez konfesije & 68 & 5,3 \\
\hline
\end{tabular}

Religijska samoidentifikacija ispitanika navedena je u tablici 3. Mjerenje je radi usporedivosti s prijašnjim istraživanjima religioznosti koja su provođena u Hrvatskoj od kraja šezdesetih godina 20. stoljeća provedeno s pomoću skale od šest stupnjeva kao odgovora na pitanje »Kada bi Vas netko pitao o Vašem odnosu prema religiji, kamo biste sami sebe svrstali? «: 1 - uvjereni sam vjernik/ica i prihvaćam sve što moja vjera uči; 2 - religiozan/na sam, premda ne prihvaćam sve što moja vjera uči; 3 - dosta

20 Slična je konfesionalna struktura i u popisu stanovništva 2011. 
razmišljam o tome, ali nisam načisto vjerujem li ili ne; 4 - prema religiji sam ravnodušan/na; 5 - nisam religiozan/na, iako nemam ništa protiv religije; 6 - nisam religiozan/na i protivnik/ica sam religije (v. Bezinović, Marinović Bobinac i Marinović Jerolimov, 2005). Kod stavljanja u odnos s drugim varijablama, pri nekim statističkim postupcima kategorije »dosta razmišljam o tome, ali nisam načisto vjerujem li ili ne« i »prema religiji sam ravnodušan/ na« spojene su u kategoriju »nesigurni i ravnodušni«, a kategorije »nisam religiozan/na, iako nemam ništa protiv religije« i »nisam religiozan/na i protivnik/ica sam religije « u kategoriju »nereligiozni i protivnici religije«.

I ispitivanje religijske samoidentifikacije pokazuje visok izraženi stupanj religioznosti u Hrvatskoj, s obzirom na to da se čak 77,3\% ispitanika izjasnilo da su religiozni, a dobiveni rezultati kad je riječ i o tome indikatoru izražene religioznosti pokazuju sličnost s rezultatima prijašnjih istraživanja provedenih s pomoću jednakoga pitanja kojim se ispitivao odnos prema religiji (usp. Marinović Jerolimov, 2005).

Tablica 3. Religijska samoidentifikacija

Table 3. Religious self-identification

\begin{tabular}{|l|c|c|}
\hline Religijska samoidentifikacija & $\mathbf{N}$ & $\mathbf{\%}$ \\
\hline Uvjereni vjernici & 592 & 45,9 \\
\hline Religiozni & 404 & 31,4 \\
\hline Nesigurni & 90 & 7,0 \\
\hline Ravnodušni & 73 & 5,7 \\
\hline Nereligiozni & 106 & 8,2 \\
\hline Protivnici religije & 24 & 1,8 \\
\hline
\end{tabular}

Križanjem rezultata konfesionalne i religijske samoidentifikacije pokazuje se da se nisu svi konfesionalno identificirani ispitanici izjasnili religioznima, odnosno da se dio ispitanika koji su se izjasnili nereligioznima konfesionalno identificira. Među ispitanicima koji su se identificirali kao katolici zajedno je 17,9\% onih koji su se izjasnili kao »nesigurni i ravnodušni« i »nereligiozni i protivnici religije«, a među onima koji su izrazili pripadnost ostalim konfesijama/religijama »nesigurnih i ravnodušnih « $\mathrm{i}$ »nereligioznih i protivnika religije« zajedno je čak 25,9\%. Takva identifikacija upućuje na složenost odnosa samoidentificirane religioznosti i konfesionalne identifikacije ispitanika, odnosno upućuje na zaključak da konfesionalna identifikacija za dio ispitanika ima značenje šire društvene i kulturne identifikacije (usp. Črpić i Zrinščak, 2005, 2010; Marinović Jerolimov, 2005; Ančić i 
Zrinščak, 2012; v. i Hervieu-Léger, 2006).

Učestalost pohađanja crkve kao jedan od pokazatelja religijske prakse ispitana je s pomoću pitanja o učestalosti odlazaka u crkvu (bogomolju) na misu (bogoslužje), s mogućim rasponom odgovora: nikada, rijetko (samo u izuzetnim životnim trenucima ili o većim blagdanima), mjesečno (približno), tjedno (približno), svaki dan (približno), toga nema u mojoj vjeri (tablica 4). S obzirom na mali broj odgovora u kategoriji »svaki dan (približno)« ona je u daljnjim analizama pridružena kategoriji »tjedno (približno)«.

Tablica 4. Religijska praksa (pohađanje crkve)

Table 4. Religious practices (church attendance)

\begin{tabular}{|l|c|c|}
\hline Pohađanje crkve & N & \% $^{*}$ \\
\hline Nikada & 121 & 9,4 \\
\hline $\begin{array}{l}\text { Rijetko (samo u izuzetnim životnim trenucima ili o većim } \\
\text { blagdanima) }\end{array}$ & 657 & 50,8 \\
\hline Mjesečno (približno) & 202 & 15,6 \\
\hline Tjedno (približno) & 277 & 21,4 \\
\hline Svaki dan (približno) & 29 & 2,2 \\
\hline
\end{tabular}

* Razlika do $100 \%$ odnosi se na odgovor »Toga nema u mojoj vjeri« $(0,5 \%)$.

Stav ispitanika prema povezanosti religijskoga i nacionalnog identiteta ispitan je s pomoću Likertove skale s pet čestica (tablica 5). S ciljem oblikovanja nezavisne varijable, koju će se staviti u odnos sa zavisnom varijablom stavova prema imigrantima ispitanih mjerenjem društvene distance prema (potencijalnim) stranim radnicima, od pet indikatora koji opisuju stavove prema povezanosti religijskoga i nacionalnog identiteta konstruirana je kompozitna varijabla, pri čemu je tvrdnja »Vjerska i nacionalna pripadnost se nikako ne mogu poistovjetiti« rekodirana obrnuto (Cronbachov $\alpha$ $=0,764)$. 
Tablica 5. Stavovi prema povezanosti religijskoga i nacionalnog identiteta (\%)

Table 5. Attitudes towards the interconnectedness of religious and national identity $(\%)$

\begin{tabular}{|l|c|c|c|c|c|c|c|c|}
\hline & $\begin{array}{c}\text { Uopće } \\
\text { se ne } \\
\text { slažem }\end{array}$ & $\begin{array}{c}\text { Ne } \\
\text { slažem } \\
\text { se }\end{array}$ & $\begin{array}{c}\text { Niti se } \\
\text { slažem, } \\
\text { niti se ne } \\
\text { slažem }\end{array}$ & $\begin{array}{c}\text { Slažem } \\
\text { se }\end{array}$ & $\begin{array}{c}\text { U } \\
\text { potpunos } \\
\text { ti se } \\
\text { slažem }\end{array}$ & N & M & SD \\
\hline $\begin{array}{l}\text { Samo katolici mogu } \\
\text { biti pravi Hrvati. }\end{array}$ & 29,09 & 26,37 & 22,09 & 14,56 & 7,88 & 1287 & 2,46 & 1,26 \\
\hline $\begin{array}{l}\text { Pripadnici vjerskih } \\
\text { manjina ne mogu biti } \\
\text { pravi Hrvati. }\end{array}$ & 21,53 & 31,55 & 30,10 & 11,05 & 5,78 & 1266 & 2,48 & 1,12 \\
\hline $\begin{array}{l}\text { Vjera i nacija su } \\
\text { nerazdruživo } \\
\text { povezane. }\end{array}$ & 13,66 & 20,08 & 31,86 & 25,90 & 8,50 & 1252 & 2,95 & 1,16 \\
\hline $\begin{array}{l}\text { Vjerska i nacionalna } \\
\text { pripadnost se nikako } \\
\text { ne mogu poistovjetiti. }\end{array}$ & 7,15 & 15,22 & 36,29 & 28,24 & 13,10 & 1257 & 3,25 & 1,09 \\
\hline $\begin{array}{l}\text { Vjerska pripadnost } \\
\text { bitna je oznaka } \\
\text { nacionalne } \\
\text { pripadnosti. }\end{array}$ & 12,34 & 23,39 & 37,43 & 20,69 & 6,16 & 1264 & 2,85 & 1,08 \\
\hline
\end{tabular}

Društvena distanca prema pripadnicima drugih religija (nekatolicima) mjerena je s pomoću prilagođene skale društvene distance sa sedam kategorija (Bogardus, 1925). ${ }^{21}$ Ispitanici su svoj odnos prema pripadnicima različitih religijskih skupina izrazili odgovorom na pitanje: »U sljedećoj tablici navedeni su pripadnici različitih religija i neki mogući odnosi s njima. Molimo Vas da za svaku skupinu zaokružite jedan broj koji predstavlja najprisniji odnos koji ste spremni prihvatiti s pripadnikom/icom te skupine.« U ispitivanje društvene distance $\mathrm{u}$ okviru toga pitanja bile su uključene sljedeće skupine: 1 - katolici; 2 - pravoslavni; 3 - muslimani; 4 - židovi; 5 - protestanti (baptisti, adventisti itd.); 6 - Jehovini svjedoci; 7 - nekršćani (Hare Krišna itd.); 8 - ateisti. Radi sažimanja kategorija, na temelju faktorske analize načinjen je kompozitni konstrukt s rezultatima društvene distance prema »nekatolicima« koji uključuje pripadnike drugih religijskih skupina

21 Teorijska osnova pojma društvene distance potječe od Simmela (1908), ali njegova je koncepcija složenija od one koja je popularizirana zahvaljujući široko prihvaćenoj uporabi Bogardusove skale društvene distance. Skala je koncipirana tako da mjeri predrasude preko određivanja stupnja bliskosti na koji pojedinci pristaju s drugim osobama (Park, 1924: 339; Bogardus, 1925). Teoretičari su uglavnom mišljenja da skala ne uključuje niti jedno značenje koje Simmel pridaje društvenoj distanci, privrženost okolini i mobilnost, emocionalnu uključenost i odvojenost te mjeru sličnosti obilježja i osjećaja između osoba (Levine, Carter i Gorman, 1976: 836), ili pak da ne istražuje društvenu distancu u sociološkom smislu (Sorokin, 1959: 10). Ipak, ne poriče se spoznajnu vrijednost uvida koji se s pomoću nje stječu. 
(Cronbachov $\alpha=0,939 ; \mathrm{M}=4,19 ; \mathrm{SD}=1,794$ ). Struktura odgovora u okviru skale koji označavaju mogući odnos prema pripadnicima drugih religijskih skupina (nekatolicima) bila je: 1 - bračni odnos $(4,0 \%) ; 2$ - osobni prijatelj (20,3\%); 3 - neposredni susjed (14,9\%); 4 - suradnik na poslu (14,9\%); 5 stanovnik u mojoj zemlji (16,9\%); 6 - posjetitelj u mojoj zemlji (16,9\%); 7 izbaciti iz moje zemlje (12,1\%).

Jedan mjerni instrument koji se odnosi na zavisne konstrukte koji opisuju stavove prema stranim (imigrantskim) radnicima uključuje također prilagođenu skalu društvene distance sa sedam kategorija. Mjerenje društvene distance kojim se htjelo utvrditi koji bi najprisniji odnos ispitanici bili spremni imati sa (potencijalnim) stranim radnicima pokazalo je prosječnu visoku društvenu distancu $(\mathrm{M}=4,29$; $\mathrm{SD}=1,998)$. Odgovori u okviru skale koji izražavaju mogući odnos prema stranim radnicima bili su: 1 - bračni odnos (9,0\%); 2 - osobni prijatelj (20,5\%); 3 - neposredni susjed $(6,8 \%) ; 4$ - suradnik na poslu (13,3\%); 5 - stanovnik u mojoj zemlji (11,4\%); 6 - posjetitelj u mojoj zemlji (25,1\%); 7 - izbaciti iz moje zemlje (13,9\%).

Radi stjecanja potpunijeg uvida u stavove prema stranim (imigrantskim) radnicima, primijenjen je još jedan mjerni instrument koji se odnosi na zavisne konstrukte koji opisuju stavove prema imigrantskim radnicima, prilagođena kombinirana skala ekonomsko-kulturne prijetnje (v. Watts, 1996; usp. Halperin, Canetti-Nisim i Pedahzur, 2007). Sedam čestica sa skalom procjene od pet stupnjeva (od 1 - »uopće se ne slažem« do 5 - »u potpunosti se slažem «), kojima su mjereni stavovi prema imigrantskim radnicima, faktorskom analizom (komponentni model, varimax rotacija i Guttman-Kaiserovov kriterij zaustavljanja ekstrakcije faktora) grupirano je u okviru dvaju faktorskih konstrukata (55,42\% varijance), od kojih jedan kao indikator opisuje imigracijsku sociokulturnu prijetnju, a drugi opisuje imigracijsku socioekonomsku prijetnju (usp. Čačić-Kumpes, Gregurović i Kumpes, 2012). ${ }^{22}$

22 Faktorski konstrukt koji se odnosi na imigracijsku sociokulturnu prijetnju okuplja sljedeće tvrdnje: »Teško bih prihvatio/la da mi radnik migrant bude šef na poslu«, »Postoji opasnost da radnici migranti unište našu kulturu i običaje $i$ »Radnici migranti se nikad neće prilagoditi vrijednostima našeg društva " (Cronbachov $\alpha=0,676$ ). Faktorski konstrukt koji se odnosi na imigracijsku socioekonomsku prijetnju okuplja sljedeće tvrdnje: »Radnici migranti bi opteretili već prezasićeno tržište radne snage u našoj zemlji«, »Naša bi vlada trebala dopustiti uvoz strane (migrantske) radne snage« (rekodirano obrnuto), "Strani radnici moraju se prilagoditi vrijednostima našeg društva ako žele raditi u njemu « $\mathrm{i}$ »U slučaju da migrantski i domaći radnik imaju jednake kvalifikacije, prednost treba uvijek dati domaćem radniku « (Cronbachov $\alpha$ $=0,641$ ). Cronbachovi $\alpha$ za oba faktora relativno su niski, moguće zbog malog broja čestica, ali i zbog mjerenja donekle nekonzistentnoga sadržaja okupljenih tvrdnji, no njihova su zasićenja na faktorima zadovoljavajuća, pa ih se u daljnjim analizama opravdano može upotrijebiti kao 
Podaci su obrađeni s pomoću računalnoga programskog paketa SPSS (Statistical Package for the Social Sciences). Pri obradi podataka primijenjene su deskriptivne analize (analiza frekvencija, tablično križanje i izračun mjera centralnih tendencija), univarijacijske analize (ANOVA i korelacijska analiza) te multivarijacijske analize (faktorska analiza i regresijska analiza).

\section{REZULTATI}

S obzirom na pretpostavku da postoji značajna povezanost između religije, odnosno religioznosti, i stavova prema određenim različitim skupinama kao što su etničke i religijske skupine, imigranti i općenito »drugi«, s namjerom da se utvrdi postoji li povezanost između religioznosti i stavova prema imigrantima, najprije valja prikazati deskriptivne pokazatelje stavljanjem $\mathrm{u}$ odnos varijabli koje se odnose na ispitane dimenzije religioznosti i varijable kojom je izražena društvena distanca prema stranim (imigrantskim) radnicima, kojom se izražava stupanj predrasudnoga stava prema »drugima«.

Slika 1. Religijska samoidentifikacija i društvena distanca prema stranim radnicima

Figure 1. Religious self-identification and social distance towards foreign workers

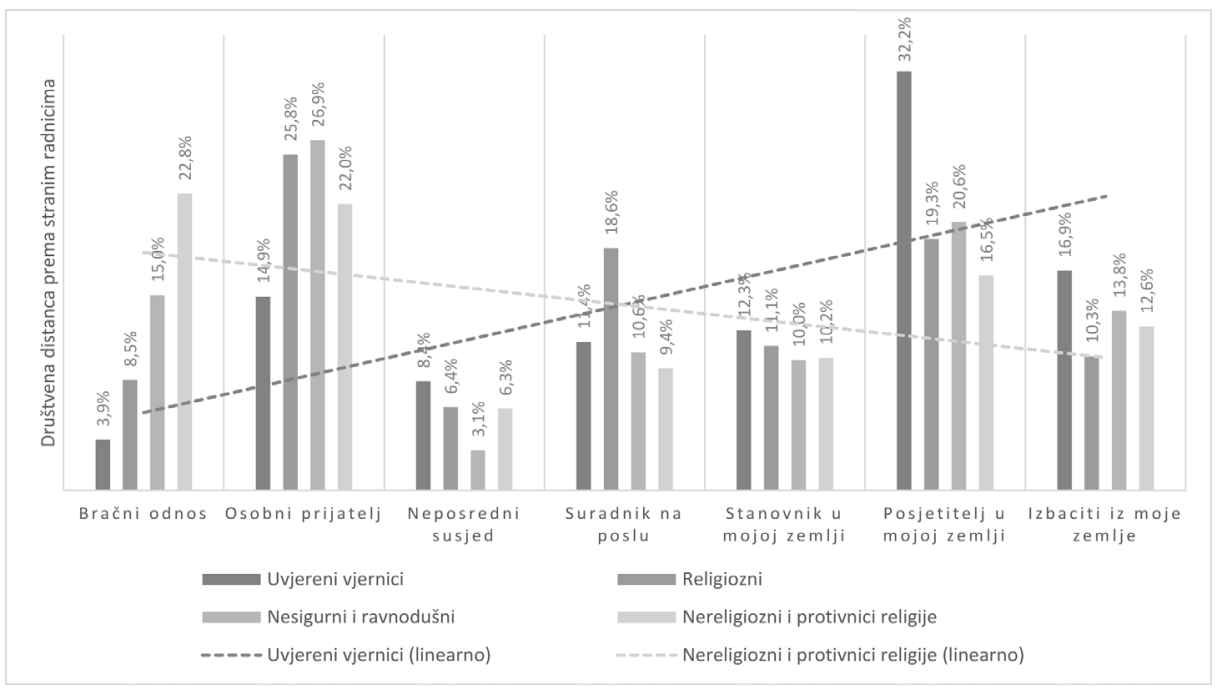

faktorske konstrukte. 
S obzirom na jedan od ciljeva istraživanja da se utvrdi postoji li povezanost između religijske samoidentifikacije, mjerene kao stupnja religioznosti ispitanika, i stavova izraženih mjerenjem društvene distance prema stranim radnicima, pokazuje se da postoji statistički značajna razlika u odgovorima, odnosno povezanost dviju varijabli $\left(\chi^{2}=112,77\right.$; $\left.\mathrm{df}=18 ; \mathrm{p}<0,001\right)$. Odgovori ispitanika u krajnjim kategorijama izražene društvene distance prema stranim radnicima u okviru kategorija religijske samoidentifikacije uglavnom su asimetrično distribuirani (v. sliku 1). Među »uvjerenim vjernicima « samo njih 18,8\% prihvatilo bi najbliskije odnose (zajedno kategorije »bračni odnos« $\mathrm{i}$ »osobni prijatelj«) sa stranim radnicima, dok se za najmanje bliske odnose (zajedno kategorije »posjetitelj u mojoj zemlji $\mathrm{i} »$ izbaciti iz moje zemlje«) odlučuje čak njih $49,1 \%$. Nasuprot tome, među »nereligioznima i protivnicima religije « udio onih koji bi prihvatili najbliskije odnose sa stranim radnicima iznosi $44,8 \%$, dok je udio onih koji su se odlučili za najmanje bliske odnose $29,1 \%$. Posebno se ističe podatak da je udio onih koji bi prihvatili bračni odnos kao najbliskiji odnos sa stranim radnicima gotovo šest puta manji među uvjerenim vjernicima $(3,9 \%)$ nego među nereligioznima i protivnicima religije $(22,8 \%)$.

Slika 2. Religijska praksa (pohađanje crkve) i društvena distanca prema stranim radnicima

Figure 2. Religious practices (church attendance) and social distance towards foreign workers

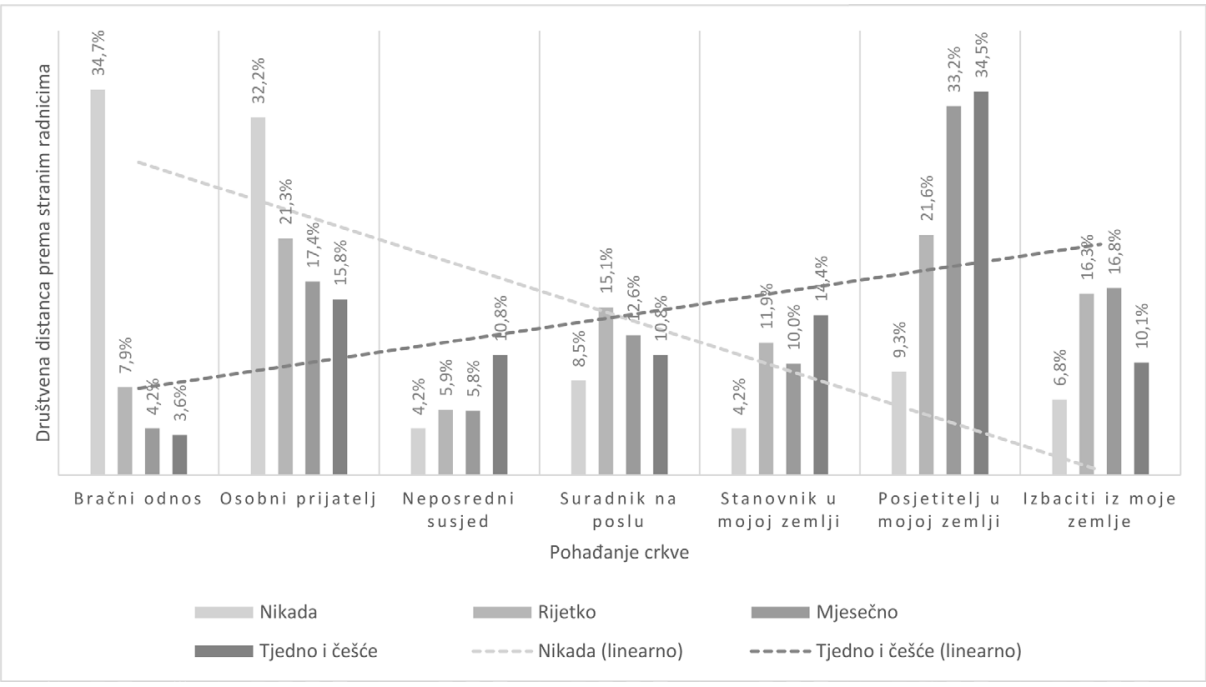


Analizom usporedbe učestalosti pohađanja crkve, kao važnog indikatora religijske prakse ispitanika, i izražene društvene distance prema stranim radnicima pokazuje se da postoji povezanost dviju varijabli $\left(\chi^{2}=176,19\right.$; $\mathrm{df}=18 ; \mathrm{p}<0,001)$. Rezultati uglavnom pokazuju asimetričnu distribuciju odgovora ispitanika u krajnjim kategorijama izražene društvene distance prema stranim radnicima s obzirom na učestalost pohađanja crkve (v. sliku 2). Tako se posebno ističe da bi među onima koji nikada ne pohađaju crkvu njih čak $66,9 \%$ prihvatilo najbliskije odnose (zajedno kategorije »bračni odnos« i »osobni prijatelj«) s imigrantskim radnicima, dok se samo njih $16,1 \%$ odlučuje za najmanje bliske odnose (zajedno kategorije »posjetitelj u mojoj zemlji« $\mathrm{i} »$ izbaciti iz moje zemlje«). Nasuprot tome, među onima koji crkvu pohađaju češće znatno je manji udio onih koji bi prihvatili najbliskije odnose sa stranim radnicima, među onima koji crkvu pohađaju mjesečno samo $21,6 \%$, a među onima koji je pohađaju tjedno i češće samo $19,4 \%$, dok je veći udio onih koji se odlučuju za najmanje bliske odnose, među onima koji crkvu pohađaju mjesečno čak $50 \%$, a među onima koji je pohađaju tjedno i češće čak $44,6 \%$.

Slika 3. Konfesionalna samoidentifikacija i društvena distanca prema stranim radnicima

Figure 3. Confessional self-identification and social distance towards foreign workers

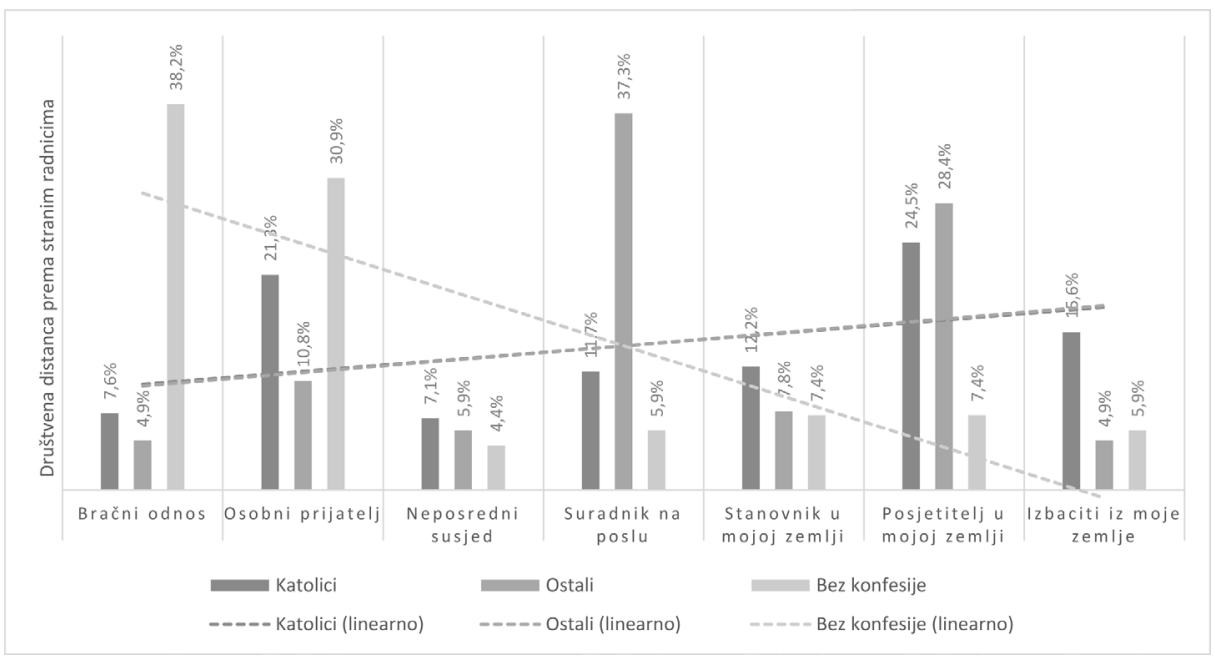

I iz analize usporedbe konfesionalne samoidentifikacije ispitanika i izražene društvene distance prema stranim radnicima utvrđeno je da postoji poveza- 
nost tih dviju varijabli $\left(\chi^{2}=147,13 ; \mathrm{df}=12 ; \mathrm{p}<0,001\right)$. Također, $\mathrm{i}$ odgovori ispitanika u okviru krajnjih kategorija društvene distance prema stranim radnicima s obzirom na kategorije konfesionalne identifikacije uglavnom su asimetrično distribuirani (v. sliku 3). Među rezultatima posebno se ističu razlike $u$ izraženoj distanci između onih koji su se konfesionalno identificirali i onih bez konfesionalne pripadnosti. Tako među onima koji su izrazili da ne pripadaju nijednoj konfesiji/religiji njih čak $69,1 \%$ prihvatilo bi najbliskije odnose (zajedno kategorije »bračni odnos« $\mathrm{i} »$ osobni prijatelj«) $\mathrm{s}$ imigrantskim radnicima, a samo se $13,3 \%$ njih odlučuje za najmanje bliske odnose (zajedno kategorije "posjetitelj u mojoj zemlji i »izbaciti iz moje zemlje«). Među onima koji su se konfesionalno identificirali znatno je manji udio onih koji bi prihvatili najbliskije odnose sa stranim radnicima od onih koji su se identificirali kao katolici, 28,9\%, a među onima koji su se identificirali kao pripadnici ostalih religija 15,7\%, dok je veći udio onih koji su spremni prihvatiti tek najmanje bliske odnose od onih koji su se identificirali kao katolici, $40,1 \%$, a među onima koji su se identificirali kao pripadnici ostalih religija $33,3 \%$.

Kako bi se utvrdilo postoje li razlike u stavovima prema imigrantima, stranim (imigrantskim) radnicima, s obzirom na razlike $\mathrm{u}$ kategorijama religijske samoidentifikacije, religijske prakse i konfesionalne samoidentifikacije, jednosmjernom analizom varijance učinjeno je testiranje razlika u predrasudnim stavovima izraženim na skali društvene distance prema stranim radnicima te razlika u stavovima prema imigrantskim radnicima koje opisuju dva faktorska konstrukta, od kojih jedan opisuje imigracijsku sociokulturnu prijetnju, a drugi imigracijsku socioekonomsku prijetnju.

Analizom varijance utvrđene su statistički značajne razlike u prosječnoj društvenoj distanci prema stranim radnicima prema sve tri dimenzije religioznosti (tablica 6). Ispitanici koji su se samoidentificirali kao »uvjereni vjernici« izražavaju statistički značajno veću društvenu distancu prema stranim radnicima od »religioznih«, »nesigurnih i ravnodušnih« $\mathrm{i} »$ nereligioznih i protivnika religije«. Oni koji nikada ne pohađaju crkvu statistički značajno izražavaju manju društvenu distancu prema stranim radnicima od onih koji je pohađaju rijetko, mjesečno ili tjedno i češće. Razlike prema konfesionalnoj identifikaciji pokazuju da oni bez konfesionalne pripadnosti statistički značajno manje izražavaju društvenu distancu prema stranim radnicima nego oni koji su se konfesionalno identificirali, tj. katolici i ostali. 
Tablica 6. Društvena distanca prema stranim radnicima s obzirom na razlike u religioznosti (ANOVA)

Table 6. Social distance towards foreign workers regarding differences in religiosity (ANOVA)

\begin{tabular}{|l|l|c|c|c|c|}
\hline & & N & M & SD & Razlike \\
\hline \multirow{4}{*}{$\begin{array}{l}\text { Religijska } \\
\text { samoidentifikacija }\end{array}$} & Uvjereni vjernici & 536 & 4,77 & 1,837 & \multirow{2}{*}{$\mathrm{F}(3,1204)=21,651$} \\
\cline { 2 - 5 } & Religiozni & 387 & 3,98 & 1,918 & \multirow{2}{*}{$\mathrm{p}=0,000, \eta^{2}=0,05$} \\
\cline { 2 - 5 } & Nesigurni i ravnodušni & 160 & 3,90 & 2,155 & $1 \neq 2,3,4$ \\
\cline { 2 - 5 } & Nereligiozni i protivnici religije & 125 & 3,61 & 2,185 & \\
\hline \multirow{4}{*}{$\begin{array}{l}\text { Religijska praksa } \\
\text { (pohađanje crkve) }\end{array}$} & Nikada & 117 & 2,68 & 1,946 & \multirow{2}{*}{$\mathrm{F}(3,1204)=33,247$} \\
\cline { 2 - 5 } & Rijetko & 623 & 4,32 & 1,993 & \multirow{2}{*}{$\mathrm{p}=0,000, \eta^{2}=0,08$} \\
\cline { 2 - 5 } & Mjesečno & 190 & 4,74 & 1,881 & $1 \neq 2,3,4$ \\
\cline { 2 - 5 } & Tjedno i češće & 278 & 4,60 & 1,773 & \multirow{2}{*}{$\mathrm{F}(2,1191)=25,617$} \\
\hline \multirow{3}{*}{$\begin{array}{l}\text { Konfesionalna } \\
\text { samoidentifikacija }\end{array}$} & Katolici & 1025 & 4,36 & 1,998 & $0,000, \eta^{2}=0,04$ \\
\cline { 2 - 5 } & Ostali & 101 & 4,36 & 1,565 & $3 \neq 1,2$ \\
\cline { 2 - 4 } & Bez konfesije & 68 & 2,60 & 1,910 & \\
\hline
\end{tabular}

S pomoću analize varijance utvrđene su statistički značajne razlike i u prosječnim stavovima prema imigrantskim radnicima koje opisuje faktorski konstrukt imigracijske sociokulturne prijetnje, i to također prema sve tri istraživane dimenzije religioznosti (tablica 7). Iz rezultata se vidi da oni koji su se samoidentificirali kao »nereligiozni i protivnici religije« izražavaju statistički značajno manji stupanj percepcije imigracijske sociokulturne prijetnje od »uvjerenih vjernika« $\mathrm{i}$ »religioznih«. Oni pak koji nikada ne pohađaju crkvu statistički značajno u manjoj mjeri percipiraju imigrante kao sociokulturnu prijetnju od onih koji je pohađaju rijetko, mjesečno ili tjedno i češće. Razlike s obzirom na konfesionalnu identifikaciju pokazuju da oni koji su se identificirali kao katolici statistički značajno više smatraju imigrante sociokulturnom prijetnjom nego oni bez konfesionalne pripadnosti.

Kad je riječ o prosječnim stavovima prema imigrantskim radnicima koje opisuje faktorski konstrukt imigracijske socioekonomske prijetnje, analizom varijance utvrđene su statistički značajne razlike samo s obzirom na religijsku samoidentifikaciju ispitanika. »Religiozni« prihvaćaju stavove koje opisuje taj faktor statistički značajno u većoj mjeri od »uvjerenih vjernika« i »nesigurnih i ravnodušnih«. 
Tablica 7. Percepcija imigracijske sociokulturne i socioekonomske prijetnje s obzirom na razlike $u$ religioznosti (ANOVA)

Table 7. Perception of immigrant sociocultural and socio-economic threat regarding the differences in religiosity (ANOVA)

\begin{tabular}{|c|c|c|c|c|c|c|}
\hline & & \multirow{2}{*}{$N$} & \multicolumn{2}{|c|}{ Sociokulturna prijetnja } & \multicolumn{2}{|c|}{ Socioekonomska prijetnja } \\
\hline & & & $\mathbf{M}$ & SD & $\mathbf{M}$ & SD \\
\hline \multirow{5}{*}{$\begin{array}{l}\text { Religijska } \\
\text { samoidentifikacija }\end{array}$} & $\begin{array}{l}\text { Uvjereni } \\
\text { vjernici }\end{array}$ & 510 & 0,137 & 1,087 & $-0,054$ & 0,981 \\
\hline & Religiozni & 383 & $-0,029$ & 0,861 & 0,150 & 0,971 \\
\hline & $\begin{array}{l}\text { Nesigurni i } \\
\text { ravnodušni }\end{array}$ & 142 & $-0,095$ & 0,986 & $-0,200$ & 1,068 \\
\hline & $\begin{array}{l}\text { Nereligiozni } \\
\text { i protivnici } \\
\text { religije }\end{array}$ & 118 & $-0,357$ & 0,949 & 0,026 & 1,051 \\
\hline & & & \multicolumn{2}{|c|}{$\begin{array}{c}\mathrm{F}(3,1149)=8,930 \\
\mathrm{p}=0,000, \eta^{2}=0,02 \\
4 \neq 1,2\end{array}$} & \multicolumn{2}{|c|}{$\begin{array}{c}\mathrm{F}(3,1149)=5,335 \\
\mathrm{p}=0,001, \eta^{2}=0,01 \\
2 \neq 1,3\end{array}$} \\
\hline \multirow{5}{*}{$\begin{array}{l}\text { Religijska praksa } \\
\text { (pohađanje crkve) }\end{array}$} & Nikada & 111 & $-0,547$ & 0,989 & 0,048 & 1,126 \\
\hline & Rijetko & 584 & 0,038 & 0,952 & 0,020 & 0,957 \\
\hline & Mjesečno & 190 & 0,113 & 0,980 & 0,091 & 0,967 \\
\hline & $\begin{array}{l}\text { Tjedno i } \\
\text { češće }\end{array}$ & 266 & 0,084 & 1,048 & $-0,110$ & 1,044 \\
\hline & & & \multicolumn{2}{|c|}{$\begin{array}{c}\mathrm{F}(3,1147)=13,226 \\
\mathrm{p}=0,000, \eta^{2}=0,03 \\
1 \neq 2,3,4\end{array}$} & \multicolumn{2}{|c|}{$\begin{array}{l}\mathrm{F}=1,761 \\
\mathrm{p}=0,153\end{array}$} \\
\hline \multirow{4}{*}{$\begin{array}{l}\text { Konfesionalna } \\
\text { samoidentifikacija }\end{array}$} & Katolici & 973 & 0,045 & 1,020 & 0,037 & 0,981 \\
\hline & Ostali & 102 & $-0,179$ & 0,819 & $-0,205$ & 1,119 \\
\hline & $\begin{array}{l}\text { Bez } \\
\text { konfesije }\end{array}$ & 65 & $-0,493$ & 0,925 & $-0,192$ & 1,141 \\
\hline & & & \multicolumn{2}{|c|}{$\begin{array}{c}\mathrm{F}(2,1137)=10,579 \\
\mathrm{p}=0,000, \eta^{2}=0,02 \\
1 \neq 3\end{array}$} & \multicolumn{2}{|c|}{$\begin{array}{l}\mathrm{F}=3,995 \\
\mathrm{p}=0,019\end{array}$} \\
\hline
\end{tabular}

Kako bi se provela hijerarhijska regresijska analiza predviđanja društvene distance prema stranim (imigrantskim) radnicima, s obzirom na religioznost, s obzirom na prihvaćanje stavova koje opisuje kompozitni konstrukt o povezanosti religijskoga i nacionalnog identiteta i s obzirom na izraženu društvenu distancu prema pripadnicima drugih religija (nekatolicima), te uz kontrolu sociodemografskih varijabli i varijabli samoprocijenjenoga socioekonomskog statusa i političke orijentacije ispitanika, potrebno je provjeriti korelacije između varijabli uključenih u regresijsku analizu, varijable društvene distance prema stranim radnicima, kao zavisne (kriterijske) varijable, i drugih varijabli kao prediktora (tablica 8). 


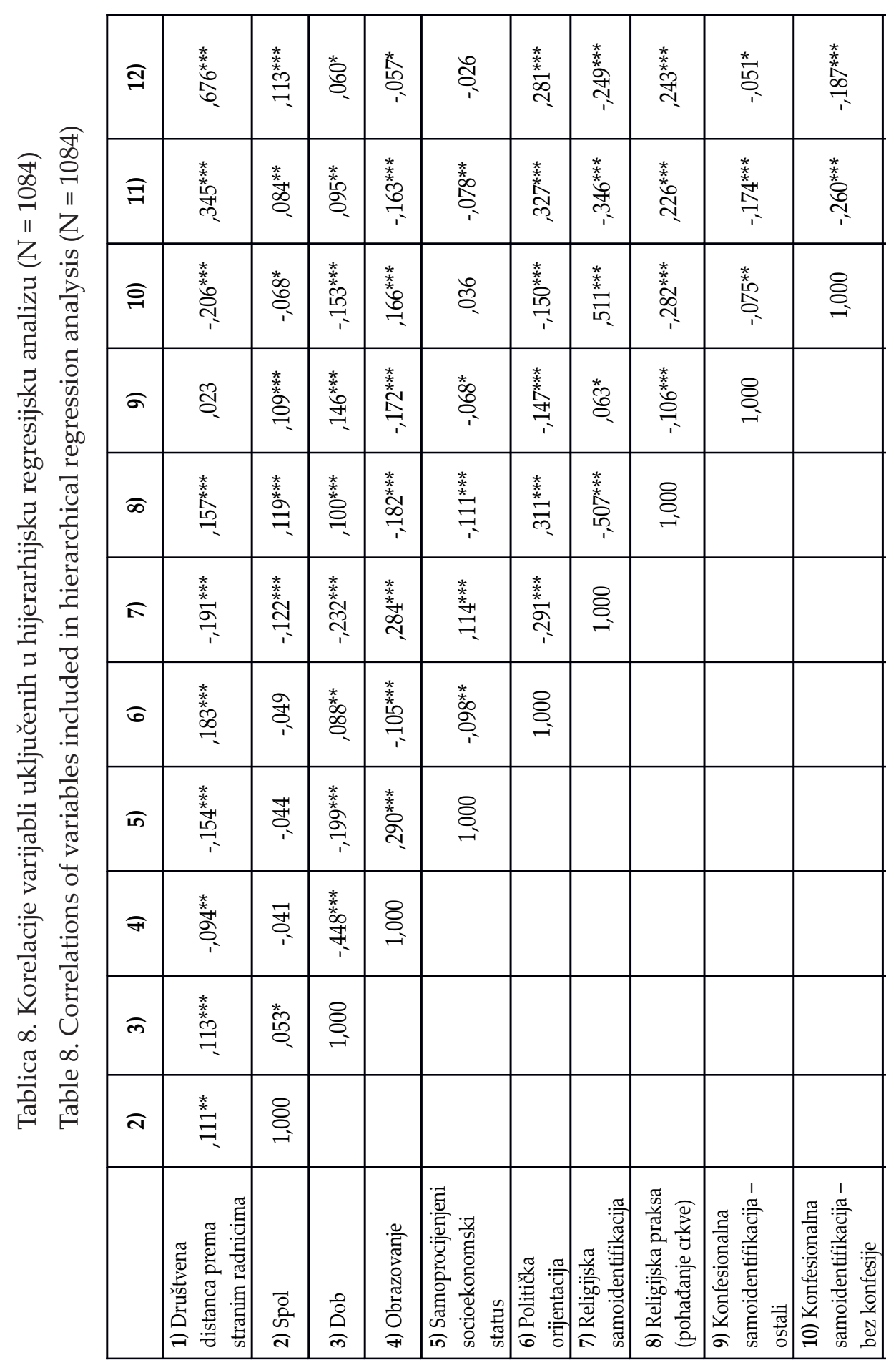




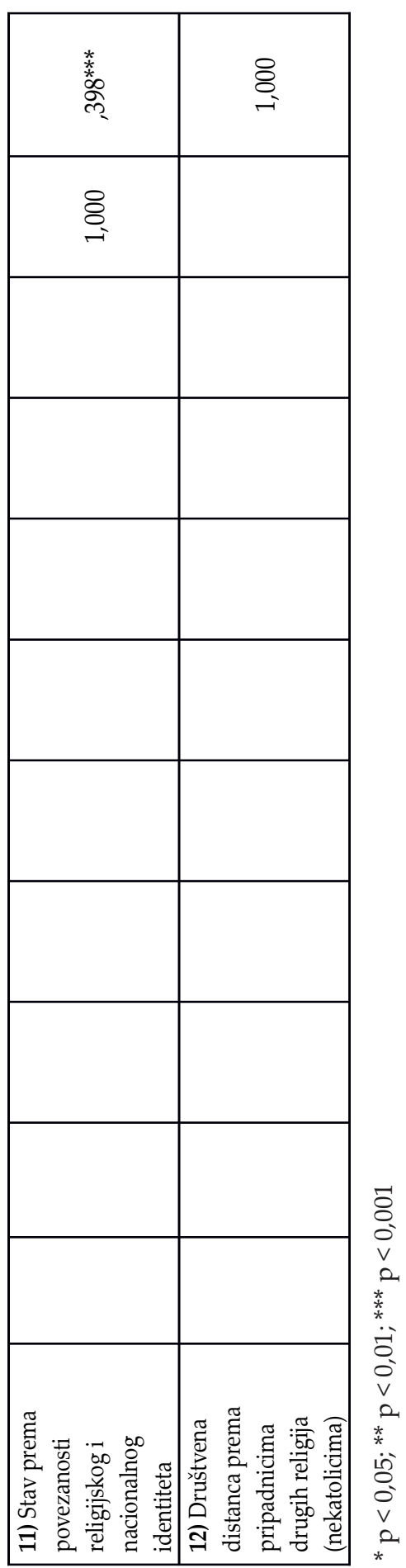


Niska, ali statistički značajna povezanost varijabli spola, dobi, obrazovanja i samoprocijenjenoga socioekonomskog statusa s kriterijskom varijablom pokazuje da veću društvenu distancu prema stranim radnicima izražavaju žene nešto više nego muškarci, stariji nešto više nego mlađi, manje obrazovani nešto više nego obrazovaniji i oni koji svoj socioekonomski status procjenjuju lošijim nego oni koji ga procjenjuju boljim (usp. Čačić-Kumpes, Gregurović i Kumpes, 2012). Relativno niska, ali statistički značajna povezanost političke orijentacije ispitanika s izraženom društvenom distancom prema stranim radnicima također očekivano pokazuje da distancu u većoj mjeri izražavaju oni politički desno nego oni politički lijevo orijentirani. Između prediktorskih varijabli kojima su ispitane tri dimenzije religioznosti (religijska samoidentifikacija kao stupanj/ne/religioznosti, religijska praksa i konfesionalna samoidentifikacija) i kriterijske varijable također je relativno niska, ali statistički značajna povezanost, a iz dobivenih se rezultata vidi da veću društvenu distancu prema stranim radnicima izražavaju oni koji se izjašnjavaju kao više religiozni nego oni koji se izjašnjavaju kao manje religiozni, odnosno kao nereligiozni, i obratno. Najveće koeficijente korelacije s kriterijskom varijablom imaju kompozitni konstrukt koji opisuje stavove prema povezanosti religijskoga i nacionalnog identiteta $(\mathrm{r}=0,345)$ i izražena društvena distanca prema pripadnicima drugih religija (nekatolicima) $(r=0,676)$, iz čega se vidi da ispitanici s višim rezultatom na tim dvama indikatorima u većoj mjeri izražavaju društvenu distancu prema stranim radnicima.

Hijerarhijska regresijska analiza provedena je u četiri koraka (modela), pri čemu je u prvom koraku pored sociodemografskih varijabli i varijabli samoprocijenjenoga socioekonomskog statusa i političke orijentacije ispitanika, kao kontrolnih prediktorskih varijabli, uključena varijabla religijske samoidentifikacije. U drugom su koraku dodane varijable koje se odnose na druga dva indikatora religioznosti, pohađanje crkve kao indikator religijske prakse i konfesionalna samoidentifikacija. U trećem koraku $\mathrm{u}$ analizu je uvrštena varijabla koja kao konstrukt opisuje stavove prema povezanosti religijskoga i nacionalnog identiteta, a u četvrtom koraku varijabla izražene društvene distance prema pripadnicima drugih religija (nekatolicima) (tablica 9). 
Tablica 9. Hijerarhijska regresijska analiza: predviđanje društvene distance prema stranim (imigrantskim) radnicima s obzirom na religioznost te uz kontrolu sociodemografskih varijabli i varijabli samoprocijenjenoga socioekonomskog statusa i političke orijentacije ispitanika

Table 9. Hierarchical regression analysis: prediction of social distance towards foreign (immigrant) workers regarding the religiosity and controlling for respondents' socio-demographic characteristics and variables of self-estimated socio-economic status and political orientation

\begin{tabular}{|c|c|c|c|c|}
\hline & \multicolumn{4}{|c|}{ Društvena distanca prema stranim radnicima } \\
\hline & Model 1 & Model 2 & Model 3 & Model 4 \\
\hline & $\beta$ & $\beta$ & $\beta$ & $\beta$ \\
\hline Spol & $0,096^{* *}$ & $0,091^{* *}$ & $0,067^{*}$ & 0,020 \\
\hline Dob & 0,052 & 0,047 & 0,050 & 0,042 \\
\hline Obrazovanje & 0,016 & 0,022 & 0,051 & 0,017 \\
\hline $\begin{array}{l}\text { Samoprocijenjeni } \\
\text { socioekonomski status }\end{array}$ & $-0,117^{* * *}$ & $-0,121^{* * *}$ & $-0,116^{* * *}$ & $-0,131^{* * *}$ \\
\hline Politička orijentacija & $0,139^{* * *}$ & $0,134^{* * *}$ & $0,066^{*}$ & $-0,028$ \\
\hline Religijska samoidentifikacija & $-0,118^{* * *}$ & $-0,032$ & 0,018 & 0,041 \\
\hline $\begin{array}{l}\text { Religijska praksa (pohađanje } \\
\text { crkve) }\end{array}$ & & 0,035 & 0,040 & $-0,028$ \\
\hline $\begin{array}{l}\text { Konfesionalna } \\
\text { samoidentifikacija } \\
\quad \text { Katolici } \\
\text { Ostali } \\
\text { Bez konfesije } \\
\end{array}$ & & $\begin{array}{c}\text { ref. } \\
0,017 \\
-0,145^{* * *}\end{array}$ & $\begin{array}{c}\text { ref. } \\
0,065^{*} \\
-0,105^{* *}\end{array}$ & $\begin{array}{c}\text { ref. } \\
0,042 \\
-0,082^{* *}\end{array}$ \\
\hline $\begin{array}{lll}\text { Stav prema } & \text { povezanosti } \\
\text { religijskog i } & \text { nacionalnog } \\
\text { identiteta } & & \\
\end{array}$ & & & $0,294^{* * * *}$ & $0,092^{* * *}$ \\
\hline $\begin{array}{l}\text { Društvena distanca } \\
\text { pripadnicima drugih } \\
\text { (nekatolicima) }\end{array}$ & & & & $0,644^{* * *}$ \\
\hline & $\begin{array}{l}R^{2}=0,081 \\
F=15,807^{\text {w* * }}\end{array}$ & $\begin{aligned} \mathrm{R}^{2} & =0,098 \\
\mathrm{~F} & =12,988 \\
\Delta \mathrm{R}^{2} & =0,017 \\
\mathrm{~F}_{\Delta \mathrm{R}}{ }^{2} & =6,837^{\text {* }}\end{aligned}$ & $\begin{array}{c}\mathrm{R}^{2}=0,166 \\
\mathrm{~F}=21,315 \\
\Delta \mathrm{R}^{2}=0,068 \\
\mathrm{~F}_{\Delta \mathrm{R}}{ }^{2}=86,908\end{array}$ & $\begin{array}{c}\mathrm{R}^{2}=0,493 \\
\mathrm{~F}=94,785 \\
\Delta \mathrm{R}^{2}=0,327 \\
\mathrm{~F}_{\Delta \mathrm{R}}{ }^{2}=692,209\end{array}$ \\
\hline
\end{tabular}

U okviru prvoga modela (koraka) 8,1\% varijance kriterijske varijable objašnjeno je sociodemografskom varijablom spola, koja prestaje biti značajnim prediktorom $u$ četvrtome modelu hijerarhijske regresijske analize, socioekonomskim statusom, koji kao sociostrukturna kontrolna varijabla zadržava statističku značajnost kao prediktor u sva četiri modela, političkom orijentacijom, koja prestaje biti značajnim prediktorom u četvrtome modelu, te religijskom samoidentifikacijom, kojom je izražen odnos prema religiji kao stupanj religioznosti. Dobiveni rezultati upućuju 
na to da su nešto više žene nego muškarci, oni lošijega samoprocijenjenog socioekonomskog statusa, oni više politički desno orijentirani te oni koji se identificiraju kao više religiozni, skloniji izraziti veću društvenu distancu prema stranim radnicima.

U drugome modelu, uključivanjem druga dva indikatora religioznosti, pohađanja crkve, kao oblika religijske prakse, i konfesionalne samoidentifikacije, objašnjeno je dodatnih $1,7 \%$ varijance kriterijske varijable. Tu se pokazuje da su oni koji su se identificirali kao katolici, za razliku od onih koji su se izjasnili da ne pripadaju nijednoj konfesiji/religiji, skloniji izraziti veću društvenu distancu prema stranim (imigrantskim) radnicima $(\beta=-0,145)$. Iako se provjerom utvrđuje da s obzirom na povezanost između prediktorskih varijabli ne postoji problem multikolinearnosti, ipak nakon otklanjanja utjecaja preklapanja s varijablama koje su uključene $\mathrm{u}$ regresijski model, $\mathrm{u}$ ovom koraku hijerarhijske regresijske analize, nakon uključivanja varijable konfesionalne identifikacije, ni paralelno uključena varijabla religijske prakse kao indikatora religioznosti ni religijska samoidentifikacija, koja se kao jedina uključena dimenzija religioznosti u okviru prvoga modela pokazala značajnim prediktorom društvene distance prema stranim radnicima, ne pokazuju se značajnim prediktorima, odnosno ne pokazuje se njihov značajan jedinstven doprinos u predikciji društvene distance prema stranim radnicima.

U okviru trećeg modela dodavanjem varijable koja kao konstrukt opisuje stavove prema povezanosti religijskoga i nacionalnog identiteta objašnjeno je dodatnih 6,8\% varijance kriterijske varijable. Dobiveni rezultat upućuje na to da $\mathrm{u}$ okviru modela ta varijabla pojedinačno najviše pridonosi objašnjenju zavisne varijable $(\beta=0,294)$, a pokazuje se da su oni koji se više slažu s tvrdnjama koje opisuju taj konstrukt skloni izraziti društvenu distancu prema stranim radnicima. Valja spomenuti da se u okviru ovoga regresijskog modela, osim još neznatne značajnosti varijabli spola i političke orijentacije, zadržane značajnosti varijable samoprocijenjenoga socioekonomskog statusa, te umanjene značajnosti varijable konfesionalne samoidentifikacije »bez konfesije«, zbog supresijskog efekta za varijablu konfesionalne samoidentifikacije »ostali« pokazuje neznatno značajan regresijski koeficijent $\beta$, iako je između te varijable i kriterijske varijable pokazana nulta korelacija.

Dodavanjem pak $\mathrm{u}$ četvrtome modelu varijable društvene distance prema pripadnicima drugih religija (nekatolicima) objašnjeno je dodatnih čak 32,7\% varijance kriterijske varijable. Taj završni regresijski model 
objašnjava $49,3 \%$ varijance kriterijske varijable, varijabla društvene distance prema pripadnicima drugih religija (nekatolicima) pokazuje se daleko najznačajnijim prediktorom $(\beta=0,644)$, a statistički značajnima pokazali su se i prediktori: samoprocijenjeni socioekonomski status, konfesionalna samoidentifikacija - bez konfesije te stav prema povezanosti religijskog i nacionalnog identiteta. Iz dobivenih rezultata zaključno proizlazi da su društvenu distancu prema stranim (imigrantskim) radnicima skloni izraziti oni koji svoj socioekonomski status procjenjuju kao lošiji, oni koji su se identificirali kao katolici, za razliku od onih koji su se izjasnili da ne pripadaju nijednoj konfesiji/religiji, oni koji imaju stav da su religijsko i nacionalno usko povezani, a osobito oni koji su skloni izraziti društvenu distancu prema pripadnicima drugih religija (nekatolicima).

\section{RASPRAVA I ZAKLJUČAK}

Istraživanje povezanosti dimenzija religioznosti i stavova prema imigrantima pokazalo je da je visoko izražena religioznost u hrvatskome društvu, kao složena pojava koja ima učinak na cjelokupno društvo, značajno povezana s ispitivanim stavovima hrvatskih građana prema (potencijalnim) imigrantima. Tako se pokazalo kao i u nekim drugim istraživanjima da se religioznost može smatrati značajnim prediktorom stavova prema imigrantima (v. Scheepers, Gijsberts i Hello, 2002: 259; Scheepers i Eisinga, 2015). To, dakako, ne znači da pojedine dimenzije religioznosti svugdje jednako i na isti način predviđaju te stavove. Scheepers, Gijsberts i Hello (2002) primjerice utvrdili su da je manja sklonost predrasudnim stavovima prema manjinama što se više prihvaćaju doktrinarna religijska uvjerenja. To se u ovom istraživanju nije pokazalo. Međutim, ključni zaključak je u oba istraživanja sličan, a to je da su osobe koje su bez konfesionalne pripadnosti, za razliku od onih koje se konfesionalno identificiraju, manje sklone pokazivati predrasude prema imigrantima. Naime rezultati ovog istraživanja pokazuju povezanost svih triju ispitivanih dimenzija religioznosti s društvenom distancom prema stranim (imigrantskim) radnicima. Oni koji se identificiraju religioznima, koji prakticiraju svoju vjeru te podjednako katolici i pripadnici drugih vjerskih skupina pokazali su znatno višu društvenu distancu prema (potencijalnim) stranim radnicima nego oni koji se identificiraju kao nereligiozni, nikad ne idu u crkvu (bogomolju) i koji su bez konfesionalne pripadnosti.

Ti se nalazi mogu u stanovitoj mjeri povezati i s Bréchonovom uspored- 
nom analizom rezultata istraživanja vrijednosti $u$ zapadnoeuropskim zemljama potkraj 20. stoljeća. Bréchon je konstatirao da je upotrebljivije razlikovati one koji sebe smatraju religioznima od onih koji to nisu nego tražiti razliku između religija. Iako se tim istraživanjem nije utvrdio jasan učinak ispitivanih dimenzija religioznosti na ksenofobne stavove, jasno se pokazalo da simbolički sustav onih koji su se izjasnili kao nereligiozni i ateisti nadilazi nacionalne granice i da ih, uz ostala istraživana vrijednosna obilježja, obilježava i manja sklonost ksenofobičnosti nego ostale (Bréchon, 2003: 140; usp. Scheepers, Gijsberts i Hello, 2002). Objašnjenje zasigurno nije jednostavno i vjerojatno bi ga, unatoč možebitnoj univerzalnosti tih nalaza, trebalo tražiti u pojedinim društvenim i povijesnim kontekstima.

Nadalje, izraženi ksenofobni stavovi u nesuglasju su s temeljnim vrijednostima religijskih učenja uz koja pristaje, prema vlastitoj identifikaciji, velik broj ispitanika (45,9\% uvjerenih vjernika, onih koji prihvaćaju sve što njihova vjera uči). S time u vezi vrijedi podsjetiti da je Allport, baveći se predrasudama u religijskome kontekstu, ustvrdio da prosječni vjernici obično malo znaju o vjerskoj doktrini pa da je objašnjenje njihovih predrasuda bolje tražiti u sociokulturnome kontekstu nego u teološkome (Allport, 1966). Budući da su Scheepers, Gijsberts i Hello (2002) u svom istraživanju religioznosti i predrasuda prema imigrantima utvrdili i to da su građani bivših komunističkih država skloniji predrasudama nego oni u državama s dugom demokratskom tradicijom, ne treba ni ovdje zanemariti ulogu političkih i religijskih institucija u oblikovanju toga sociokulturnoga konteksta.

Važnost sociokulturnoga konteksta napominju i Vučković Juroš, Dobrotić i Zrinščak (2014), a na nju upućuje i utvrđena povezanost ispitivanih dimenzija religioznosti s percepcijom imigracijske kulturne i ekonomske prijetnje. Sve tri istraživane dimenzije religioznosti bolje predviđaju sociokulturnu nego socioekonomsku prijetnju, a kao i na skali društvene distance i ovdje se pokazalo da su primjerice konfesionalno identificirani (a među njima više katolici) u prosjeku značajno više nego oni koji ne pripadaju nijednoj religiji skloniji strane radnike percipirati kao prijetnju. Pokazalo se da ispitanici, unatoč lošim gospodarskim prilikama u Hrvatskoj u vrijeme istraživanja (v. Čačić-Kumpes, Gregurović i Kumpes, 2012), strane radnike ponajprije doživljavaju kao kulturnu prijetnju. Slično tome i druga istraživanja u mnogim drugim europskim zemljama potvrđuju otpor prema kulturnoj različitosti i prema imigrantima (v. npr. Bello, 2013; Schneider, 2008; Castles, 2007; Halperin, Canetti-Nisim i Pedahzur, 2007; Sni- 
derman i Hagendoorn, 2007; Zárate i sur., 2004; McLaren, 2003; Scheepers, Gijsberts i Coenders, 2002), što upućuje na univerzalnost problema kojega je, osim strukturnim razlozima, moguće tumačiti i otpornošću i raširenošću primordijalnih uvjerenja. U skladu s tim uvjerenjima, pridošlice se nastoji prihvaćati prema njihovu etničkom, nacionalnom ili »rasnom« podrijetlu. Joppke (2004) kaže da su u suvremenim liberalnim zemljama primordijalna uvjerenja prestala oblikovati imigracijsku politiku iako to ne znači da su ona zato i nestala. Dapače, budući da je primordijalizam reduciran u modernim državnim institucijama, upozorava Joppke, teže ga je kontrolirati. Kad je riječ o novim demokracijama, primordijalna privrženost zamjetna je $\mathrm{u}$ ideološkom primordijalizmu nacionalističkih politika i populizmu. Pritom ne treba zaboraviti ni s jedne strane revitalizaciju religije (v. Borowik, 2007) i odnos između (dominantne) crkve i države (v. npr. Zrinščak i sur., 2014), a s druge raširenu tendenciju kulturalizacije religije (Brubaker, 2017; usp. Hervieu-Léger, 2006). U tim je procesima možda moguće tražiti kulturnokontekstno objašnjenje nalaza Scheepersa, Gijsberts i Hello (2002) o izraženijim predrasudama prema imigrantima u postkomunističkim državama.

Sveukupno, na površinu bez obzira je li riječ o starim ili novim demokracijama kao važan kriterij razine otvorenosti prema imigrantima isplivavaju kako religioznost ispitanika u zemljama (makar i potencijalnog) primitka tako i religijska pripadnost imigranata (v. npr. Sniderman i Hagendoorn, 2007), pa se nameće i zaključak o religiji kao manje ili više (ne)propusnoj simboličkoj granici. Kad je riječ o Hrvatskoj, na taj zaključak dodatno navodi i prediktivna snaga dviju varijabli potvrđena u načinjenoj regresijskoj analizi od kojih se jedna odnosi na pristajanje uz shvaćanje da su religijski i nacionalni identitet nerazdvojivi, a druga na izraženu društvenu distancu prema pripadnicima drugih religija (nekatolicima). Istraživanje pokazuje da su društvenu distancu prema stranim (imigrantskim) radnicima skloni izraziti oni koji imaju stav da su religijsko i nacionalno usko povezani, odnosno oni koji se slažu s tvrdnjama da »samo katolici mogu biti pravi Hrvati«, da »pripadnici vjerskih manjina ne mogu biti pravi Hrvati«, da su »vjera i nacija (...) nerazdruživo povezane«, da se »vjerska i nacionalna pripadnost (...) mogu poistovjetiti« te da je »vjerska pripadnost bitna (...) oznaka nacionalne pripadnosti «. Osim potvrde religije kao simboličke granice, moglo bi se reći da ti rezultati u određenoj mjeri govore u prilog pretpostavke Sekulića i Šporer (2006) i Sekulićeva zaključka o povezanosti nacionalizma i religioznosti (Sekulić, 2012). To otvara prostor 
za razmatranje religijskog nacionalizma o kojem govori Roger Friedland (2011) kad tvrdi da su suvremeni nacionalizmi natopljeni religijom te da religijski univerzalizam nije u proturječju s nacionalizmom. No kad je riječ o hrvatskome kontekstu, za objašnjenje dobivenih rezultata koji upućuju na to da su religiozniji ispitanici skloni izraziti veću društvenu distancu prema imigrantima vrijedilo bi uzeti u obzir i koncepciju »kolektivističkih religija«, koje su također identitetski usmjerene, ali ne nužno isključive kao što je to kada je riječ o »religijskom nacionalizmu « (Jakelić, 2006; Zrinščak, 2014). Pretpostavka je naime ponajprije da sa snažnijom unutargrupnom identifikacijom raste društvena distanca prema onima koji toj skupini ne pripadaju (Driedger i Peters, 1977).

Naposljetku, pokazalo se da bi izražena društvena distanca većinske domaće populacije prema stranim radnicima, ako prihvatimo poopćeno Simmelovo objašnjenje društvene distance prema kojem ona ne dopušta da se pripadnici druge skupine vide kao pojedinci i stoga »ne ostavlja mogućnost njihova povezivanja ni na koji temeljni način osim da zajedno čine 'društvo' " (Simmel, 1908: 2), mogla biti ozbiljnom preprekom dolasku imigranata i njihovoj integraciji. Utvrđena povezanost triju razmatranih dimenzija religioznosti s visoko izraženom društvenom distancom, kao i izražena društvena distanca prema pripadnicima drugih religija (nekatolicima), upućuju na moguće, iako ne i jedine izvore problema i mogućih odgovora na dolazak (imigrantskih) stranih radnika. Sve to zahtijeva dodatno razmatranje s društveno-povijesnog aspekta, a nameće i potrebu sveobuhvatnije analize $u$ metodološkom i disciplinarnom smislu. 


\section{LITERATURA}

Agier, M. (2013). La condition cosmopolite. L'anthropologie à l'épreuve du piège identitaire. Paris: La Découverte.

Allport, G. W. (1966). The Religious Context of Prejudice, Journal for the Scientific Study of Religion, 5 (3): 447-457, doi: https://doi.org/10.2307/1384172

Ančić, B. i Zrinščak, S. (2012). Religion in Central European Societies: Its Social Role and People's Expectations, Religion and Society in Central and Eastern Europe, 5 (1): 21-38.

Bail, Ch. A. (2008), The Configuration of Symbolic Boundaries against Immigrants in Europe, American Sociological Review, 73 (1): 37-59, doi: https://doi.org/10.1177/000312240807300103

Bauman, Z. (2002). Reconnaissance Wars of the Planetary Frontierland, Theory, Culture $\mathcal{E}$ Society, 19 (4): 81-90, doi: https://doi.org/10.1177/0263276402019004006

Bauman, Z. (2004). Wasted Lives: Modernity and its Outcasts. Cambridge: Polity Press.

Bauman, Z. (2016). Strangers at Our Door. Cambridge: Polity Press.

Bello, V. (2013). Attitudes towards immigrants in European Societies: A comparison between the Perceived Group Threats Theory and the Intercultural Values Theory through a multi-level analysis. Barcelona: United Nations University Institute on Globalization, Culture and Mobility (UNU-GCM) (Policy Report 01/10).

Bezinović, P., Marinović Bobinac, A. i Marinović Jerolimov, D. (2005). Kratka ljestvica religioznosti: validacija na uzorku adolescenata, Društvena istraživanja, 14 (1-2): 135153.

Bogardus, E. S. (1925). Measuring Social Distance, Journal of Applied Sociology, 9: 299-308.

Borowik, I. (2007). The Religious Landscape of Central and Eastern Europe after Communism, u: J. A. Beckford i N. J. Demerath III (ur.). The Sage Handbook of the Sociology of Religion. London: SAGE Publications, 654-669, doi: https://doi.org/10.4135/9781848607965.n32

Bréchon, P. (2003). Integration into Catholicism and Protestantism in Europe: The Impact on Moral and Political Values, u: L. Halman i O. Riis (ur.). Religion in Secularizing Society: The Europeans' Religion at the End of 20th Century. Leiden - Boston: Brill, 114 161.

Brubaker, R. (2015). Grounds for difference. Cambridge - London: Harvard University Press.

Brubaker, R. (2017). Between nationalism and civilizationism: the European populist moment in comparative perspective, Ethnic and Racial Studies, 40 (8): 1191-1226, doi: https://doi.org/10.1080/01419870.2017.1294700

Casanova, J. (2007). Immigration and the New Religious Pluralism: A European Union/ United States Comparison, u: Th. Banchoff (ur.). Democracy and the New Religious Pluralism. New York: Oxford University Press, 59-83, doi: https://doi.org/10.1093/ac 
prof:oso/9780195307221.003.0005

Castles, S. (2007). Twenty-First-Century Migration as a Challenge to Sociology, Journal of Ethnic and Migration Studies, 33 (3): 351-371, doi: https://doi. org/10.1080/13691830701234491

Ceobanu, A. M. i Escandell, X. (2010). Comparative Analyses of Public Attitudes Toward Immigrants and Immigration Using Multinational Survey Data: A Review of Theories and Research, Annual Review of Sociology, 36: 309-328, doi: https://doi. org/10.1146/annurev.soc.012809.102651

Citrin, J. i Sides, J. (2008). Immigration and the Imagined Community in Europe and the United States, Political Studies, 56 (1): 33-56, doi: https://doi.org/10.1111/j.14679248.2007.00716.x

Čačić-Kumpes, J., Gregurović, M. i Kumpes, J. (2014). Generacijske razlike u odnosu prema etničkoj različitosti: stavovi hrvatskih srednjoškolaca i njihovih roditelja, Revija za sociologiju, 44 (3): 235-285, doi: https://doi.org/10.5613/rzs.44.3.2

Čačić-Kumpes, J., Gregurović, S. i Kumpes, J. (2012). Migracija, integracija i stavovi prema imigrantima u Hrvatskoj, Revija za sociologiju, 42 (3): 305-336, doi: https://doi. org/10.5613/rzs.42.3.3

Čapo, J. (2015). Od Opatovca do Strasbourga: razna lica izbjegličke »krize«, Zbornik Trećeg programa Hrvatskog radija, 87: 5-17.

Črpić, G. i Zrinščak, S. (2005). Između identiteta i svakodnevnog života: religioznost u hrvatskom društvu iz europske komparativne perspektive, u: J. Baloban (ur.). U potrazi za identitetom. Komparativna studija vrednota: Hrvatska i Europa. Zagreb: Golden marketing-Tehnička knjiga, 45-83.

Črpić, G. i Zrinščak, S. (2010). Dinamičnost u stabilnosti: religioznost u Hrvatskoj 1999. i 2008. godine, Društvena istraživanja, 19 (1-2 /105-106/): 3-27.

Davidov, E. i Semyonov, M. (2017). Attitudes toward immigrants in European societies, International Journal of Comparative Sociology, 58 (5): 359-366, doi: https://doi. org/10.1177/0020715217732183

Driedger, L. i Peters, J. (1977). Identity and social distance: towards understanding Simmel's 'The Stranger', Canadian Review of Sociology / Revue canadienne de sociologie, 14 (2): 158-173, doi: https://doi.org/10.1111/j.1755-618x.1977.tb00339.x

European Commission (2018). Integration of immigrants in the European Union. Report. Special Eurobarometer 469, doi: https://doi.org/10.2837/918822

European Parliament (2017). Attitudes towards immigration in Europe: myths and realities. European Social Survey ERIC,

https://www.europeansocialsurvey.org/docs/findings/IE_Handout_FINAL.pdf (14. 12. 2018.).

Evrigenis, [D]. (1985). Report drawn up on behalf of the Committee of Inquiry into the Rise of Fascism and Racism in Europe on the findings of the Committee of Inquiry. EU European 
Parliament Document (Working Documents 1985-1986, Document A 2-160/85).

Foner, N. i Alba, F. (2008). Immigrant Religion in the U.S. and Western Europe: Bridge or Barrier to Inclusion, International Migration Review, 42 (2): 360-392, doi: https://doi. org/10.1111/j.1747-7379.2008.00128.x

Friedland, R. (2001). Religious Nationalism and the Problem of Collective Representation, Annual Review of Sociology, 27: 125-152, doi: https://doi.org/10.1146/annurev. soc. 27.1 .125

Fullin, G. (2016). Labour market outcomes of immigrants in a South European country do race and religion matter, Work, Employment and Society, 30 (3):391-409, doi: https:// doi.org/10.1177/0950017015575867

Futile debates around the Global Compact for Migration are a missed opportunity for all, EU migrants included (2018). https://www.migrationnewssheet.eu/features/ futile-debates-around-the-global-compact-for-migration-are-a-missed-opportunityfor-all-eu-migrants-included (15. 12. 2018.).

Gołębiowska, E. (2009). Ethnic and Religious Tolerance in Poland, East European Politics and Societies, 23 (3): 371-391, doi: https://doi.org/10.1177/0888325409333191

Gow, D. i Meyer, H. (ur.) [2016]. Brexit: The Politics of a Bad Idea. London: Friedrich-EbertStiftung - Social Europe, https://www.socialeurope.eu/wp-content/uploads/2016/05/ Brexit-The-Politics-of-a-Bad-Idea.pdf (10. 12. 2018.).

Halperin, E., Canetti-Nisim, D. i Pedahzur, A. (2007). Threatened by the uncontrollable: Psychological and socio-economic antecedents of social distance towards labor migrants in Israel, International Journal of Intercultural Relations, 31 (4): 459-478, doi: https://doi.org/10.1016/j.ijintrel.2007.01.003

Hello, E., Scheepers, P. i Gijsberts, M (2002). Education and Ethnic Prejudice in Europe: Explanations for cross-national variances in the educational effect on ethnic prejudice, Scandinavian Journal of Educational Research, 46 (1): 5-24, doi: https://doi. org/10.1080/00313830120115589

Hervieu-Léger, D. (2001). La religion en miettes ou la question des sectes. Paris: CalmannLévy.

Hervieu-Léger, D. (2006). La démocratie providentielle, temps de l'ultra-sécularisation, Revue européenne des sciences sociales, 46 (135): 111-121, doi: https://doi.org/10.4000/ ress.261

Hervieu-Léger, D. (2007). Islam and the Republic: The French Case, u: Th. Banchoff (ur.). Democracy and the New Religious Pluralism. New York: Oxford University Press, 203221, doi: https://doi.org/10.1093/acprof:oso/9780195307221.003.0012

Hodžić, A. (2011). Bošnjaci u Zagrebu (kratki prikaz socijalno-kulturnog stanja). Zagreb: Vijeće bošnjačke nacionalne manjine Grada Zagreba.

Huddleston, Th. i Mikaba, P. (2017). Policymakers: Be as bold as your constituents and support a welcoming Europe!, u: European Parliament. Attitudes towards 
immigration in Europe: $m y$ ths and realities. European Social Survey ERIC, https://www. europeansocialsurvey.org/docs/findings/IE_Handout_FINAL.pdf (14. 12. 2018.).

International Organization for Migration (IOM) (2017). World Migration Report 2018. Geneva.

Jakelić, S. (2006). Secularization, European Identity, and »The End of the West «, The Hedgehog Review - Critical Reflections on Contemporary Culture, 8 (1-2): 133-139.

Jenkins, R. (2015). Boundaries and borders, u: J. Jackson i L. Molokotos-Liederman (ur.). Nationalism, Ethnicity and Boundaries: Conceptualising and Understanding Identity through Boundary Approaches. London - New York: Routledge, 11-27.

Johnson Shen, M., Yelderman, L. A., Haggard, M. C. i Rowatt, W. C. (2013). Disentangling the belief in God and cognitive rigidity/flexibility components of religiosity to predict racial and value-violating prejudice: A Post-Critical Belief Scale analysis, Personality and Individual Differences, 54 (3): 389-395, doi: https://doi.org/10.1016/j. paid.2012.10.008

Joppke, Ch.(2004).PrimordialBeliefs and Immigration Policy: The CaseofBritain's Patrials, u: J. C. Alexander, G. T. Marx i Ch. L. Williams (ur.). Self, Social Structure, and Beliefs: Explorations in Sociology. Berkeley - Los Angeles - London: University of California Press, 195-215, doi: https://doi.org/10.1525/california/9780520241367.003.0013

Karyotis, G. i Patrikios, S. (2010). Religion, securitization and anti-immigration attitudes: The case of Greece, Journal of Peace Research, 47 (1): 43-57, doi: https://doi. org/10.1177/0022343309350021

Kivisto, P. (2016). International Migration, u: D. Yamane (ur.). Handbook of Religion and Society. Cham: Springer, 547-568, doi: https://doi.org/10.1007/978-3-319-31395-5_27

Knoll, B. R. (2009). »And Who Is My Neighbor?« Religion and Immigration Policy Attitudes, Journal for the Scientific Study of Religion, 48 (2): 313-331, doi: https://doi. org/10.1111/j.1468-5906.2009.01449.x

Kuzio, T. (2001). Transition in Post-Communist States: Triple or Quadruple?, Politics, 21 (3): 168-177, doi: https://doi.org/10.1111/1467-9256.00148

Lamont, M. (1992). Money, Morals, and Manners: The Culture of the French and the American Upper-Middle Class. Chicago - London: The University of Chicago Press, doi: https:// doi.org/10.7208/chicago/9780226922591.001.0001

Lamont, M. i Molnár, V. (2002). The Study of Boundaries in the Social Sciences, Annual Review of Sociology, 28 (1): 167-195, doi: https://doi.org/10.1146/annurev. soc.28.110601.141107

Levine, D. N., Carter, E. B. i Miller Gorman, E. (1976). Simmel's influence on American sociology, American Journal of Sociology, 81 (4): 813-845, doi: https://doi. $\operatorname{org} / 10.1086 / 226143$

Marinović Jerolimov, D. (2005). Tradicionalna religioznost u Hrvatskoj 2004.: između kolektivnoga i individualnoga, Sociologija sela, 43 (2 /168/): 303-338. 
Mathieu, S. (2010). Le musulman, cet immigré: la perception des musulmans par des nonmusulmans du XVe arrondissement de Paris, u: L. Endelstein, S. Fath i S. Mathieu (ur.). Dieu change en ville. Religion, espace, immigration. Paris: L'Harmattan, 75-91.

McLaren, L. M. (2003). Anti-Immigrant Prejudice in Europe: Contact, Threat Perception, and Preferences for the Exclusion of Migrants, Social Forces, 81 (3): 909-936, doi: https://doi.org/10.1353/sof.2003.0038

Minkenberg, M. (2017). The Radical Right in Eastern Europe. New York: Palgrave Pivot Springer Nature, doi: https://doi.org/10.1057/978-1-137-56332-3

Mujadžević, D. (2014). The Consolidation of the Islamic Community in Modern Croatia: A Unique Path to the Acceptance of Islam in a Traditionally Catholic European Country, Journal of Muslims in Europe, 3: 66-93, doi: https://doi.org/10.1163/2211795412341276

Nagayoshi, K. i Hjerm, M. (2015). Anti-immigration attitudes in different welfare states: Do types of labor market policies matter?, International Journal of Comparative Sociology, 56 (2): 141-162, doi: https://doi.org/10.1177/0020715215591379

Nail, Th. (2015). The Figure of the Migrant. Stanford: Stanford University Press.

Nelson, T. D. (ur.) (2009). Handbook of Prejudice, Stereotyping, and Discrimination. New York: Psychology Press, doi: https://doi.org/10.4324/9781841697772

Nikodem, K. (2011). Religija i crkva: pitanja institucionalne religioznosti u suvremenom hrvatskom društvu, Socijalna ekologija, 20 (1): 5-30.

Offe, C. (2004). Capitalism by Democratic Design? Democratic Theory Facing the Triple Transition in East Central Europe, Social Research, 71 (3): 501-528.

Pace, E. (2014). Increasing Religious Diversity in a Society Monopolized by Catholicism, u: G. Giordan i E. Pace (ur.). Religious Pluralism: Framing Religious Diversity in the Contemporary World. Cham: Springer, 93-114, doi: https://doi.org/10.1007/978-3-31906623-3_7

Park, R. E. (1924). The Concept of Social Distance as Applied to the Study of Racial Attitudes and Racial Relations, Journal of Applied Sociology, 8: 339-344.

Perrineau, P. (2016). Europeans and the Migratory Issue, Fondation Robert Schuman European issues, 403, https://www.robert-schuman.eu/en/doc/questions-d-europe/ qe-403-en.pdf (15. 12. 2018.).

Pickel, G. (2018) Perceptions of Plurality: The Impact of the Refugee Crisis on the Interpretation of Religious Pluralization in Europe, u: U. Schmiedel i G. Smith (ur.). Religion in the European Refugee Crisis. Cham: Palgrave Macmillan, 15-37, doi: https:// doi.org/10.1007/978-3-319-67961-7_2

Rydgren, J. (ur.) (2018). The Oxford Handbook of the Radical Right. New York: Oxford University Press, doi: https://doi.org/10.1093/oxfordhb/9780190274559.001.0001

Schain, M. A. (2017). The extreme-right and immigration policy-making: measuring direct and indirect effects, u: C. Mudde (ur.). The Populist Radical Right: A Reader. 
London - New York: Routledge, 458-473.

Scheepers, P. i Eisinga, R. (2015). Religiosity and Prejudice against Minorities, u: J. D. Wright (ur.). International Encyclopedia of the Social \& Behavioral Sciences. London: Elsevier Science, 381-383, doi: https://doi.org/10.1016/b978-0-08-097086-8.84058-1

Scheepers, P., Gijsberts, M. i Coenders, M. (2002). Ethnic Exclusionism in European Countries: Public Opposition to Civil Rights for Legal Migrants as a Response to Perceived Ethnic Threat, European Sociological Review, 18 (1): 17-34, doi: https://doi. org/10.1093/esr/18.1.17

Scheepers, P., Gijsberts, M. i Hello, E. (2002). Religiosity and Prejudice against Ethnic Minorities in Europe: Cross-National Tests on a Controversial Relationship, Review of Religious Research, 43 (3): 242-265, doi: https://doi.org/10.2307/3512331

Schneider, S. L. (2008). Anti-Immigrant Attitudes in Europe: Outgroup Size and Perceived Ethnic Threat, European Sociological Review, 24 (1): 53-67, doi: https://doi. org/10.1093/esr/jcm034

Sekulić, D. (2012). Društveni okvir i vrijednosti, Revija za sociologiju, 42 (3): 231-275, doi: https://doi.org/10.5613/rzs.42.3.1

Sekulić, D. i Šporer, Ž. (2006). Religioznost kao prediktor vrijednosnih orijentacija, Revija za sociologiju, 37 (1-2): 1-19.

Semyonov, M., Raijman, R. i Gorodzeisky A. (2006). The Rise of Anti-Foreigner Sentiment in European Societies, 1988-2000, American Sociological Review, 71 (3): 426-449, doi: https://doi.org/10.1177/000312240607100304

Sides, J. i Citrin, J. (2007). European Opinion About Immigration: The Role of Identities, Interests and Information, British Journal of Political Science, 37 (3): 477-504, doi: https://doi.org/10.1017/s0007123407000257

Simmel, G. (1908). Soziologie. Untersuchungen über die Formen der Vergesellschaftung. Leipzig: Duncker \& Humblot.

Sniderman, P. M. i Hagendoorn, L. (2007). When Ways of Life Collide: Multiculturalism and Its Discontents in the Netherlands. Princeton - Oxford: Princeton University Press.

Sorokin, P. A. (1959). Social and Cultural Mobility. New York: The Free Press.

Strabac, Z., Aalberg, T. i Valenta, M. (2014). Attitudes towards Muslim Immigrants: Evidence from Survey Experiments across Four Countries, Journal of Ethnic and Migration Studies, 40 (1): 100-118, doi: https://doi.org/10.1080/1369183x.2013.831542

Trittler, S., Mandes, S. i Koenig, M. (2015). Religious Dimensions of National and European Identities: Evidence from Cross-national Survey Research, u: W. Spohn, M. Koenig i W. Knöbl (ur.). Religion and National Identities in an Enlarged Europe. Basingstoke: Palgrave Macmillan, 124-145, doi: https://doi.org/10.1057/9780230390775_6

Understanding Pegida in Context (2015). London: Social Europe - Friedrich-Ebert-Stiftung, https://www.socialeurope.eu/focus/understanding-pegida-in-context (15. 12. 2018.). 
Vrcan, S. (2001). Vjera u vrtlozima tranzicije. Split: Glas Dalmacije - Revija Dalmatinske akcije.

Vrcan, S. (2006). A Preliminary Challenge: Borders or Frontiers?, Social Compass, 53 (2): 215-226, doi: https://doi.org/10.1177/0037768606064330

Vučković Juroš, T., Dobrotić, I. i Zrinščak, S. (2014). Socijalna distanca i društveno okruženje: Manjinske skupine u postkomunističkim i južnoeuropskim zemljama, u: J. Baloban, K. Nikodem i S. Zrinščak (ur.). Vrednote u Hrvatskoj i u Europi: komparationa analiza. Zagreb: Kršćanska sadašnjost - Katolički bogoslovni fakultet Sveučilišta u Zagrebu, 217-257.

Walton, J. (2015). Labours of Inter-religious Tolerance Cultural and Spatial Intimacy in Croatia and Turkey, The Cambridge Journal of Anthropology, 33 (2): 59-76, doi: https:// doi.org/10.3167/ca.2015.330206

Watts, M. W. (1996). Political Xenophobia in the Transition from Socialism: Threat, Racism and Ideology among East German Youth, Political Psychology, 17 (1): 97-126, doi: https://doi.org/10.2307/3791945

Wike, R., Stokes, B. i Simmons, K. (2016). Europeans Fear Wave of Refugees Will Mean More Terrorism, Fewer Jobs. Sharp ideological divides across EU on views about minorities, diversity and national identity. Washington: Pew Research Center, http://assets. pewresearch.org/wp-content/uploads/sites/2/2016/07/14095942/Pew-ResearchCenter-EU-Refugees-and-National-Identity-Report-FINAL-July-11-2016.pdf (15. 12. 2018.).

Zárate, M. A., Garcia, B., Garza, A. A. i Hitlan, R. T. (2004). Cultural threat and perceived realistic group conflict as dual predictors of prejudice, Journal of Experimental Social Psychology, 40 (1): 99-105, doi: https://doi.org/10.1016/s0022-1031(03)00067-2

Zrinščak, S. (2014). Re-Thinking Religious Diversity: Diversities and Governance of Diversities in »Post-Societies«, u: G. Giordan i E. Pace (ur.). Religious Pluralism: Framing Religious Diversity in the Contemporary World. Cham: Springer, 115-131, doi: https://doi.org/10.1007/978-3-319-06623-3_8

Zrinščak, S., Marinović Jerolimov, D., Marinović, A. i Ančić, B. (2014). Church and State in Croatia: Legal Framework, Religious Instruction, and Social Expectations, u: S. P. Ramet (ur.). Religion and Politics in Post-Socialist Central and Southeastern Europe: Challenges since 1989. Basingstoke: Palgrave Macmillan, 131-154.

Župarić-Iljić, D. i Gregurović, M. (2013). Stavovi studenata prema tražiteljima azila u Republici Hrvatskoj, Društvena istraživanja, 22 (1): 41-62, doi: https://doi.org/10.5559/ di.22.1.03 


\title{
Religiosity and Attitudes towards Immigrants in Croatia
}

\author{
Josip Kumpes
}

\section{SUMMARY}

Migration has become a burning issue of the contemporary world, while immigrants are the "incarnation of outsiders". Although research shows that most Europeans support open Europe, spreading moral panic is one of the more frequent responses to migration. Politicians and the media, especially those on the right and the far right side of the political spectrum, try to represent immigrants as a security problem and every other kind of problem for all, even potential, recipient countries. Xenophobophilia, i.e. the political exploitation of xenophobic tendencies in the general population, is on the rise together with xenophobia, which forms a kind of social perpetuum mobile of the third kind. The public discourse often associates immigrants coming from predominantly Islamic countries with terrorism, as if they were Islamists, thus instilling the fear of mass migration from the Islamic world and of possibly devastating Islamic influence on the Christian cultural foundations of contemporary immigration societies. In this context, the question of whether traditional immigration countries as well as new or potential ones are ready and able to face the contemporary challenges of religion. In essence, the dynamics of the relationship between immigrants and the receiving society and the need for its understanding make the issue of religion, among other factors, both complex and unavoidable in migration research. This connection was mainly observed either from the perspective of the sociology of migration or the sociology of religion, which determined the focus and aspect of linking the two phenomena. Therefore, this paper first offers a brief insight into previous sociological research from both perspectives, and then tries to pose the issue of sociological research of the relationship between religion and migration with a study conducted in Croatia on a representative sample of adult citizens.

An insight into theoretical and empirical research of this relationship shows that they are socially and historically determined in many facets. This is obvious in the differences in the topics that sociologists focus on and which arise from the social and historical context within which they are being explored. Contextual differences in multi-national research represent a problem for researchers, confronting them with theoretical limitations and methodological challenges. Problems of terminological ambiguities arise in these situations, which are further complicated by comparative research and the narrowing of theoretical and analytical focus on theories of competitive threat both on an individual and macro level. As the social and historical context in a way determines the subject and methodology of research, knowledge of it is important for the analysis and interpretation of research results. This is also observed in the research of symbolic boundaries towards immigrants and their possible transformation into social boundaries. When the relationship between symbolic and social boundaries is thought of in connection to contemporary mass migration, the symbolic boundaries are expressed in individual attitudes towards immigrants, and social boundaries can be recog- 
nised in the consequences of these attitudes: materialised in disorderly and poor living conditions in refugee settlements at the borders, fencing of state borders with walls and razor wire, formed in immigration policies, expressed in active resistance to the establishment of centres for asylum seekers in local communities, etc. In this context, where most of the immigrants come from predominantly Muslim countries to a predominantly Christian Europe, religion is seen as a symbolic boundary that needs to be the focus of research. Starting from this point of view, and from the fact that the importance of religion as a symbolic border, as well as other ethnic markers and cultural features, varies from society to society, Croatian society makes a good example for several reasons. Croatian society has a long history of multi-ethnicity and multi-confessionalism within multi-ethnic and multi-confessional states. In the past, ethnic differentiation primarily relied on religion as a cultural symbolic boundary, and in many respects it still does so. The transitional period and the new-found state independence were characterised by strong national homogenisation and a war at the end of the 20th century, and by joining the European Union, the population of the traditionally emigrant society was presented with the possibility of an even easier emigration, but the potential for an inflow of immigrants also increased.

Croatia's state borders became more open than ever for bi-directional population migration, which raises the question of whether the symbolic and social boundaries followed the same transformation. In addition to answering this question and given the social context in which religiousness is strongly expressed, and the arrival of immigrants is more of a possibility than a reality, the main aim of the research was to try to determine whether some of the examined dimensions of religiosity (religious self-identification, confessional self-identification and religious practice) can be considered as predictors of Croatian citizens' attitudes toward (potential) immigrants.

The empirical research using the survey method was conducted from June to September 2009 on a representative stratified sample of 1300 adult citizens of Croatia. In addition to socio-demographic characteristics of respondents and their self-estimated socio-economic status, used as independent control variables, and expressed political orientation of respondents as an additional control variable within the regression analysis, within the framework of the research from the wider survey questionnaire, the analysis uses instruments related to major independent measures, the dimensions of religiosity, instruments related to independent constructs, a measure describing the attitude of the relation between religious and national identity, and a measure describing the social distance towards religious groups, and instruments related to dependent constructs describing attitudes towards foreign (immigrant) workers.

In relation to the posited research questions of whether there is a connection between the examined dimensions of religiosity (religious self-identification, confessional self-identification and religious practice) as independent variables and attitudes towards foreign (immigrant) workers, the expressed social distance and the perception of threat of immigration, as dependent variables, a connection has been determined. Analysis of variance (ANOVA) determined statistically significant differences in average social distance towards foreign workers according to all three dimensions of religiosity. Respondents who self-identified as most religious, as "convinced believers", express a statistically significantly greater social distance towards foreign workers than the "religious", "unsure and indifferent" 
and "non-religious and opposing religions" respondents. Those who never attend church express a statistically significant smaller social distance towards foreign workers than those who attend it rarely, on a monthly or weekly basis, or even more frequently. Differences in confessional identification show that those without confessional affiliation are statistically significantly less likely to express social distance towards foreign workers than those that identified confessionally, i.e. Catholics and others.

Using the analysis of variance, statistically significant differences in average attitudes towards immigrant workers were determined and described by the factor construct of the sociocultural immigration threat, according to all three researched dimensions of religiosity. The results show that those who self-identified as "nonreligious and opposing religions" express a statistically significant lower degree of perceiving the sociocultural immigration threat than the "convinced believers" and "religious". Those who never attend church perceive immigrants as less of a sociocultural threat than those who attend it rarely, on a monthly or weekly basis, or even more frequently, to a statistically significant degree. Differences in confessional identification show that those who identified as Catholics are statistically significantly more likely to view immigrants as a sociocultural threat than those without a confessional affiliation. When it comes to average attitudes towards immigrant workers described by the factor construct of the immigration socio-economic threat, analysis of variance found statistically significant differences only with respect to the religious self-identification of the respondents. The "religious" accept the views that describe this factor to a statistically significant greater extent than the "convinced believers" and the "unsure and indifferent".

Finally, a hierarchical regression analysis of predicting social distance towards foreign (immigrant) workers has been carried out in four steps (models), with respect to the examined dimensions of religiosity, with respect to attitudes towards the connection of religious and national identity, and with respect to the expressed social distance towards members of other religions (non-Catholics), and with control for socio-demographic variables (gender, age and education) and variables of self-estimated socio-economic status and political orientation of respondents.

Religious self-identification within the first model $(\beta=-0.118)$ proved to be a significant predictor, and the result suggests that those who identify as more religious are more inclined to express greater social distance towards foreign workers. After the inclusion of the other two religiosity indicators in the second model, religious practice and confessional self-identification, the result shows that those who identified as Catholics, unlike those who expressed that they do not belong to any confession, are more inclined to express a greater social distance towards foreign (immigrant) workers $(\beta=-0.145)$. In the third model, a variable was added which describes attitudes to the connection between religious and national identity as a construct, which revealed that this variable contributes the most to the explanation of the dependent variable $(\beta=0.294)$, demonstrating that those who are more in agreement with the statements describing that construct tend to express greater social distance towards foreign workers. In the fourth regression model, explaining $49.3 \%$ of the variance of the criterion variable, the addition of the variable of social distance towards members of other religions (non-Catholics) explains an additional $32.7 \%$ of the variance, and this variable proves to be by far the most significant predictor $(\beta=0.644)$. From the results obtained, it follows that social 
distance towards foreign (immigrant) workers is more likely to be expressed by those who evaluate their socio-economic status as inferior, those who identified themselves as Catholics, unlike those who expressed that they do not belong to any confession, those who hold the view that religious and national identities are closely related, and especially those who are inclined to express social distance to members of other religions (non-Catholics).

It is concluded that the researched dimensions of religiosity have been shown, as is the case in some other studies, as significant predictors of attitudes toward (potential) immigrants. In addition, since the respondents who identify themselves as more religious are more inclined to xenophobic attitudes than those who identified as less religious or non-religious, expressed religious identity, especially confessional identity, is shown to be a symbolic boundary towards (potential) immigrants in the Croatian society, and this is also indicated by the finding that those who accept the view that the religious and national identity are closely related and those who are inclined to express social distance to members of other religions (non-Catholics) tend to express a high social distance towards foreign (immigrant) workers. The results of the research also point to the validity of the assumption that highly expressed religiosity, especially confessional identification, points to a wider social and cultural identity to a large extent.

KEY WORDS: religion, religiosity, migration, symbolic boundaries, social distance, attitudes towards immigrants 